\title{
On the choice of the driving temperature for eddy-covariance carbon dioxide flux partitioning
}

\author{
G. Lasslop ${ }^{1, *}$, M. Migliavacca ${ }^{2}$, G. Bohrer ${ }^{3}$, M. Reichstein ${ }^{1}$, M. Bahn ${ }^{4}$, A. Ibrom ${ }^{5}$, C. Jacobs ${ }^{6}$, P. Kolari ${ }^{7}$, D. Papale ${ }^{8}$, \\ T. Vesala ${ }^{7}$, G. Wohlfahrt ${ }^{4}$, and A. Cescatti ${ }^{2}$ \\ ${ }^{1}$ Max Planck Institute for Biogeochemistry, Biogeochemical Model-Data Integration Group, Jena, Germany \\ ${ }^{2}$ European Commission, Joint Research Centre, Institute for Environment and Sustainability, \\ Climate Risk Management Unit, Ispra, Italy \\ ${ }^{3}$ Department of Civil, Environmental \& Geodetic Engineering, The Ohio State University, OH, USA \\ ${ }^{4}$ Institute of Ecology, University of Innsbruck, Innsbruck, Austria \\ ${ }^{5}$ Centre for Ecosystems and Environmental Sustainability, Department of Chemical and Biochemical, \\ Technical University of Denmark (DTU), Denmark \\ ${ }^{6}$ Wageningen UR, Alterra, Wageningen, The Netherlands \\ ${ }^{7}$ Department of Forest Sciences, University of Helsinki, Finland \\ ${ }^{8}$ Department for Innovation in Biological, Agro-food and Forest systems (DIBAF), Univ. of Tuscia, Viterbo, Italy \\ *now at: Max Planck Institute for Meteorology, Bundesstr. 53, 20146 Hamburg, Germany
}

Correspondence to: G. Lasslop (gitta.lasslop@mpimet.mpg.de)

Received: 5 June 2012 - Published in Biogeosciences Discuss.: 31 July 2012

Revised: 1 November 2012 - Accepted: 19 November 2012 - Published: 18 December 2012

\begin{abstract}
Networks that merge and harmonise eddycovariance measurements from many different parts of the world have become an important observational resource for ecosystem science. Empirical algorithms have been developed which combine direct observations of the net ecosystem exchange of carbon dioxide with simple empirical models to disentangle photosynthetic (GPP) and respiratory fluxes $\left(R_{\mathrm{eco}}\right)$. The increasing use of these estimates for the analysis of climate sensitivities, model evaluation and calibration demands a thorough understanding of assumptions in the analysis process and the resulting uncertainties of the partitioned fluxes. The semi-empirical models used in flux partitioning algorithms require temperature observations as input, but as respiration takes place in many parts of an ecosystem, it is unclear which temperature input - air, surface, bole, or soil at a specific depth - should be used. This choice is a source of uncertainty and potential biases.

In this study, we analysed the correlation between different temperature observations and nighttime NEE (which equals nighttime respiration) across FLUXNET sites to understand the potential of the different temperature observations as input for the flux partitioning model. We found that the differ-
\end{abstract}

ences in the correlation between different temperature data streams and nighttime NEE are small and depend on the selection of sites. We investigated the effects of the choice of the temperature data by running two flux partitioning algorithms with air and soil temperature. We found the time lag (phase shift) between air and soil temperatures explains the differences in the GPP and $R_{\text {eco }}$ estimates when using either air or soil temperatures for flux partitioning. The impact of the source of temperature data on other derived ecosystem parameters was estimated, and the strongest impact was found for the temperature sensitivity. Overall, this study suggests that the choice between soil or air temperature must be made on site-by-site basis by analysing the correlation between temperature and nighttime NEE. We recommend using an ensemble of estimates based on different temperature observations to account for the uncertainty due to the choice of temperature and to assure the robustness of the temporal patterns of the derived variables. 


\section{Introduction}

Eddy-covariance measurements have contributed strongly to our understanding of ecosystem responses to climate with respect to water, carbon and energy fluxes (Law et al., 2002; Falge et al., 2002; Teuling et al., 2010; Mahecha et al., 2010, and many more).

To analyse changes in the observed net ecosystem exchange (NEE) with respect to the underlying processes photosynthesis and respiration, NEE is often partitioned into gross primary production (GPP) and ecosystem respiration $\left(R_{\text {eco }}\right)$. This procedure is usually based on semi-empirical models of respiration, which use temperature as a driver. Respiratory fluxes are generated by many components of an ecosystem, e.g., leaves, branches, stems, but also belowground, by soil organisms and roots. The temperature driving the respiration processes varies between the different locations where they take place (Subke and Bahn, 2010). Moreover eddy-covariance systems observe the flux above the canopy and, therefore, not at the time when the fluxes form, but rather delayed by the transport time from the location of respiration to the sensor (Phillips et al., 2011). This heterogeneity within the ecosystem influences the relationship between observed fluxes and temperature: it can appear as noise or hysteresis patterns may occur. Trying to account for this heterogeneity to improve model performance strongly increases the complexity and, therefore, the number of parameters in the flux partitioning model. However, keeping the model's structure simple is an important goal in order to remain as close as possible to the data, to avoid additional assumptions, and to avoid additional sources of uncertainty. Currently, frequently used flux-partitioning algorithms choose only one temperature stream, and it remains unclear which temperature (air, $T_{\text {air }}$ or soil, $T_{\text {soil }}$, in a specific soil depth, or the surface temperature, $T_{\text {surf }}$ ) is the most appropriate (Subke and Bahn, 2010). Moreover, hysteresis can lead to systematic under- or overestimation in flux-partitioning algorithms that selectively fit only daytime or nighttime data and then extrapolate the model in time.

The collection and harmonisation of eddy-covariance observations from stations all over the world (www.fluxdata. org) and methodological developments now allow for global gridded datasets of carbon fluxes based on local eddycovariance flux measurements to be derived (Beer et al., 2010). In addition to the value of having a global estimate based on observations, these global gridded datasets are highly promising for land surface model validation and improvement (Bonan et al., 2011). For such studies precise uncertainty estimates strongly increase the usefulness of the data. The uncertainty of the GPP estimate has been partly considered in some studies by including estimates based on daytime and nighttime data, but both algorithms rely on air temperature (and not soil temperature) as a driver for respiration (Beer et al., 2010; Lasslop et al., 2010).
The goal of our study is to improve our understanding of potential biases and uncertainties in flux partitioning algorithms as affected by the choice of the driving temperature and with this our understanding on how to best use these estimates. We first illustrate how differences between air and soil temperature can influence flux partitioning algorithms. We investigate the potential of air and soil temperatures as drivers for the Lloyd and Taylor (Lloyd and Taylor, 1994) respiration model across FLUXNET sites. We quantify the uncertainty and potential biases arising from the choice of the driving temperature for respiration. We further try to attribute the differences between the annual flux components derived with the air and soil temperatures to statistical measures of the relationship between air and soil temperatures and to vegetation structure. Moreover, we quantify the difference in ecosystem parameters derived during the flux partitioning using either air or soil temperature.

\section{Methods}

\subsection{Data}

We used data from the FLUXNET "La Thuile" database (www.fluxdata.org, version of December 2007) containing 976 site-years of half hourly eddy-covariance data. The data are $\mathrm{CO}_{2}$ storage change corrected, spike filtered, $u_{*}$-filtered ( $u_{*}$ is the friction velocity), and subsequently gap-filled ( $\mathrm{Pa}-$ pale et al., 2006). A flux partitioning algorithm is applied that partitions the net exchange into GPP and $R_{\text {eco }}$ (Reichstein et al., 2005). In spite of this high level of harmonisation, the derivation of half-hourly fluxes from the high frequency raw data still varies from site to site (Mauder et al., 2008). For the analysis only sites providing the necessary data with a high quality, i.e., the data necessary to apply the flux partitioning and retrieve reliable annual sums were used. We could include $270 \mathrm{yr}$ from 90 sites.

We used air and soil temperature observations; air temperature is usually measured above the canopy close to the eddycovariance system. The depth of soil temperature observations varies between sites (see Table 1). When multiple soil temperatures were available, we used the observation closest to the surface, assuming that the top layer is usually the largest source of respiration in soils. In addition to these two temperature data streams, we computed the surface temperature, $T_{\text {surf }}$, based on longwave radiation for sites measuring the radiation components (see Table 1). The surface temperature can be derived as:

$T_{\text {surf }}=\left(\frac{L_{\text {out }}-(1-\epsilon) L_{\text {in }}}{\sigma_{\mathrm{B}} \epsilon}\right)^{1 / 4}$

which is based on the Stefan-Boltzmann law. Here, $\sigma_{\mathrm{B}}$ denotes the Stefan-Boltzmann constant, $L_{\text {out }}$ is the longwave outgoing radiation, $L_{\text {in }}$ is the longwave incoming radiation and $\epsilon$ is the emissivity of the surface, here set to 0.98 , which 
Table 1. List of FLUXNET sites and years used, reference, values of LAI and SOC included in the analysis, column LW indicates whether longwave radiation was available for the specific site and $d$ is the measurement depth of the soil temperature in $m$.

\begin{tabular}{|c|c|c|c|c|c|c|}
\hline sites & years & reference & LAI & SOC & LW & $d$ \\
\hline AT-Neu & 2003 & Wohlfahrt et al. (2008) & 6.5 & 4.25 & & 0.05 \\
\hline AU-Fog & 2006 & - & - & - & $\mathrm{x}$ & \\
\hline AU-Tum & 2003 & Van Gorsel et al. (2008) & 2.4 & - & & 0.02 \\
\hline BE-Lon & 2005,2006 & Moureaux et al. (2006) & 5.4 & 3.7 & & \\
\hline BE-Vie & 1997-2008,2000-2003,2005-06 & Aubinet et al. (2001) & 5.1 & 3.82 & & \\
\hline BR-Sa2 & 2001 & Sakai et al. (2004) & 4.91 & - & $\mathrm{x}$ & \\
\hline BW-Ma1 & 2000 & Veenendaal et al. (2004) & 1.3 & 0.5 & $\mathrm{x}$ & \\
\hline CA-Ca1 & 1999,2002 & Humphreys et al. (2006) & 8.4 & - & $\mathrm{x}$ & \\
\hline $\mathrm{CA}-\mathrm{Ca} 2$ & $2001-2005$ & Humphreys et al. (2006) & 2.2 & - & & \\
\hline $\mathrm{CA}-\mathrm{Ca} 3$ & $2002-2005$ & Humphreys et al. (2006) & 6.7 & - & $\mathrm{x}$ & \\
\hline CA-Let & 1999-2005 & Flanagan et al. (2002) & 0.8 & - & & \\
\hline CA-Mer & 1999-2005 & Lafleur et al. (2003) & 1.3 & - & $\mathrm{x}$ & 0.02 \\
\hline CA-Oas & 1997-2000, 2002-2005 & Black et al. (2000) & 2.1 & 1.63 & $\mathrm{x}$ & \\
\hline CA-Obs & 2000-2003, 2005 & Bergeron et al. (2007) & 3.8 & - & $\mathrm{x}$ & \\
\hline CA-Ojp & 2000-2003, 2005 & Howard et al. (2004) & 2.6 & 1.58 & $\mathrm{x}$ & \\
\hline CA-Qcu & 2002-2003, 2005, 2006 & Giasson et al. (2006) & 0.82 & - & $\mathrm{x}$ & \\
\hline CA-Qfo & 2004 & Bergeron et al. (2007) & 3.7 & 3.5 & $\mathrm{x}$ & \\
\hline CA-SJ3 & 2005 & Zha et al. (2009) & 2.9 & - & $\mathrm{x}$ & \\
\hline CA-TP4 & 2004 & Arain and Restrepo-Coupe (2005) & 8 & 3.7 & $\mathrm{x}$ & 0.02 \\
\hline CA-WP1 & 2004-2005 & Syed et al. (2006) & 2.61 & - & $\mathrm{x}$ & \\
\hline CN-Do1 & 2005 & Yan et al. (2008) & 5.1 & - & $\mathrm{x}$ & \\
\hline CN-Do2 & 2005 & Yan et al. (2008) & 3.78 & - & $\mathrm{x}$ & \\
\hline CN-Do3 & 2005 & Yan et al. (2008) & 1.63 & - & $\mathrm{x}$ & \\
\hline DE-Bay & 1998-1999 & Staudt and Foken (2007) & 5.3 & 17.02 & & 0.02 \\
\hline DE-Geb & 2004-2006 & Anthoni et al. (2004) & - & - & $\mathrm{x}$ & 0.02 \\
\hline DE-Gri & 2006 & Prescher et al. (2010) & 4.93 & - & $\mathrm{x}$ & \\
\hline DE-Hai & 2001,2003 & Knohl et al. (2003) & 6.08 & 12.2 & & 0.05 \\
\hline DE-Har & $2005-2006$ & Schindler et al. (2006) & - & - & $\mathrm{x}$ & \\
\hline DE-Kli & 2005 & Prescher et al. (2010) & 4.7 & 9.7 & $\mathrm{x}$ & \\
\hline DE-Tha & 1998-2000, 2003-2006 & Grünwald and Bernhofer (2007) & 8 & 16 & $\mathrm{x}$ & \\
\hline DE-Wet & 2004,2006 & Rebmann et al. (2010) & 4.78 & - & $\mathrm{x}$ & 0.02 \\
\hline DK-Sor & 1997-2002, 2005-06 & Pilegaard et al. (2003) & 5 & - & $\mathrm{x}$ & 0.02 \\
\hline ES-ES1 & $1999-00,2005-06$ & Reichstein et al. (2005) & 2.63 & - & & \\
\hline ES-ES2 & 2006 & - & 3.015 & - & $\mathrm{x}$ & \\
\hline ES-LMa & 2004-2005 & - & 2 & 3.32 & $\mathrm{x}$ & \\
\hline ES-VDA & 2004 & Gilmanov et al. (2007) & 1.35 & & & \\
\hline FI-Hyy & 1997, 1999, 2001-2002, 2004 & Suni et al. (2003b) & 6.7 & 5.6 & & $0.01-0.05$ \\
\hline FI-Sii & 2005 & Aurela et al. (2007) & 0.4 & - & & \\
\hline FI-Sod & 2001, 2005-2006 & Suni et al. (2003a) & 1.2 & 3.14 & & \\
\hline FR-Fon & 2006 & - & 5.055 & 10.2 & & \\
\hline FR-Hes & $1998,2003-2006$ & Granier et al. (2000) & 6.7 & 7.17 & $\mathrm{x}$ & 0.05 \\
\hline HU-Bug & 2006 & Nagy et al. (2007) & 1.5 & - & & \\
\hline IT-BCi & 2005 & Reichstein et al. (2003a) & 5.8 & - & & \\
\hline IT-Cpz & 1997,2003 & Garbulsky et al. (2008) & 3.5 & 4.31 & & \\
\hline IT-Ro1 & $2002-2005$ & Rey et al. (2002) & $3.03,2.42$ & 11.3 & $\mathrm{x}$ & \\
\hline IT-Ro2 & 2002-2003, 2006 & Tedeschi et al. (2006) & 3.9 & 11.3 & & \\
\hline IT-SRo & 2001-2003, 2006 & Chiesi et al. (2005) & 4.2 & 2.15 & $\mathrm{x}$ & \\
\hline JP-Mas & $2002-2003$ & Saito et al. (2005) & 5.45 & - & & \\
\hline JP-Tom & $2001-2003$ & Hirano et al. (2003) & 9.2 & - & $\mathrm{x}$ & \\
\hline NL-Loo & 2005-2006 & Elbers et al. (2011) & 2.03 & 2.4 & $\mathrm{x}$ & 0.03 \\
\hline RU-Fyo & 1999-2000, 2003-2006 & Kurbatova et al. (2008) & 2.8 & - & $\mathrm{x}$ & 0.05 \\
\hline SE-Nor & $1996-1997$ & Lagergren et al. (2008) & 4.53 & & & \\
\hline UK-Gri & 1998 & Rebmann et al. (2005) & 7 & 15 & & \\
\hline US-ARM & $2003-2005$ & Fischer et al. (2007) & $2.9,1.6$ & - & $\mathrm{x}$ & \\
\hline
\end{tabular}


Table 1. Continued.

\begin{tabular}{|c|c|c|c|c|c|c|}
\hline sites & years & reference & LAI & SOC & LW & $d$ \\
\hline US-Bkg & 2005-2006 & Gilmanov et al. (2005) & 3 & - & $\mathrm{x}$ & \\
\hline US-Bo1 & 97-1998, 2000, 2005-2006 & Meyers and Hollinger (2004) & 5.5 & - & $\mathrm{x}$ & \\
\hline US-Bo2 & 2006 & Meyers and Hollinger (2004) & - & - & $\mathrm{x}$ & \\
\hline US-FPe & 2004-2006 & - & 2.5 & - & $\mathrm{x}$ & \\
\hline US-Goo & 2006 & - & 2 & - & $\mathrm{x}$ & \\
\hline US-Ha1 & $1995,1998,2001$ & Urbanski et al. (2007) & 4.5 & 8.8 & & \\
\hline US-IB1 & 2006 & Allison et al. (2005) & 1.75 & 6.3 & & \\
\hline US-IB2 & 2005-2006 & Allison et al. (2005) & $3.96,3.03$ & 6.3 & & \\
\hline US-KS2 & 2002, 2004-2005 & Powell et al. (2006) & 2.5 & 3.6 & & \\
\hline US-MMS & $2003-2005$ & Schmid et al. (2000) & $4.7,4.8,4.4$ & 6.6 & $\mathrm{x}$ & 0.05 \\
\hline US-MOz & 2006 & Gu et al. (2006) & 4.01 & - & $\mathrm{x}$ & \\
\hline US-Me3 & 2004-2005 & Vickers et al. (2009) & 0.52 & 10 & & \\
\hline US-NR1 & $2000,2002-2003$ & Monson et al. (2002) & 5.6 & 16 & $\mathrm{x}$ & \\
\hline US-Ne1 & 2003 & Verma et al. (2005) & 2.8 & 18.4 & & 0.02 \\
\hline US-Ne2 & 2004 & Verma et al. (2005) & 4.4 & 21.1 & & 0.02 \\
\hline US-Ne3 & 2003-2004 & Verma et al. (2005) & 4.27 & - & & 0.02 \\
\hline US-PFa & 1999 & Davis et al. (2003) & 4.05 & 20.2 & & \\
\hline US-SO2 & 2004-2006 & Lipson et al. (2005) & 3 & 0.87 & & \\
\hline US-SO3 & $2005-2006$ & Lipson et al. (2005) & 1.1 & - & & \\
\hline US-SO4 & 2004-2006 & - & 3 & - & & \\
\hline US-SP1 & 2005 & Powell et al. (2008) & 5.5 & 8 & & 0.1 \\
\hline US-SP2 & 2001, 2004 & Bracho et al. (2012) & $1.05,6.85$ & - & & 0.1 \\
\hline US-UMB & $2000,2002-2003$ & Nave et al. (2011) & $4.59,4.26,4.47$ & 3.6 & & \\
\hline US-Var & 2001-2003, 2006 & $\mathrm{Xu}$ and Baldocchi (2004) & 2.5 & - & & \\
\hline US-WBW & 1995,1999 & Wilson and Baldocchi (2001) & 5.75 & - & & \\
\hline US-WCr & 2000,2002 & Cook et al. (2004) & 5.4 & 9.47 & $\mathrm{x}$ & \\
\hline
\end{tabular}

is a common value for green vegetation (Humes et al., 1994). The correlation analysis here is based on the growing season only, thus, minimising a potential effect of the seasonality of the emissivity.

For the definition of the growing season (or carbon uptake period), several methods for the extraction of the growing season from GPP time-series are available. These methods include curve fitting with logistic functions of the time series and the use of derivatives of the smoothed time-series. The use of simple thresholds has proved to be well-suited and straightforward for this kind of application, particularly when the growing season is extracted from a GPP time series (e.g. Richardson et al., 2010). Here, we scaled GPP, such that the 0.05 quantile was zero and the 0.95 quantile was equal to one. Then we extracted all the values between the first and the last days in which GPP was higher than 0.2 (i.e., $20 \%$ of the 0.95 quantile -0.05 quantile range). The threshold of $20 \%$ was considered as a well-suited threshold, and it is similar to values reported in literature for similar application (e.g., Richardson et al., 2010 uses $25 \%$ of all GPP data).

Maximum leaf area index (LAI) and soil organic carbon (SOC) data were used in the analysis of differences in air or soil temperatures for flux partitioning, when these data were available on www.fluxdata.org.
A detailed set of soil temperature observations at Hyytiälä in Finland, including 5 measurement depths at 5 locations around the eddy-covariance tower, was used to investigate the influence of measurement depth and the number of soil temperature sensors.

\subsection{Flux partitioning algorithms}

Flux partitioning algorithms divide the net carbon exchange into photosynthetic uptake and respiratory release based on the fact that photosynthesis is zero during the night, i.e., without light. Most algorithms rely on simple empirical models, but neural network approaches or more complex land surface models have also been applied (Desai et al., 2008). Here two widely used approaches are included: one that fits nighttime NEE data with a respiration model and another that avoids nighttime data and uses a combination of a light response curve and a respiration model to fit daytime NEE. Both flux partitioning algorithms described here are also available as online tools at http://www.bgc-jena.mpg.de/ MDIwork/ eddyproc/. 


\subsubsection{Nighttime data based estimate}

The first flux partitioning algorithm follows the description in Reichstein et al. (2005). The algorithm fits a respiration model to the measured nighttime NEE data and extrapolates the optimised model to daytime periods using the respective temperature observations of the day. An Arrhenius-type model after Lloyd and Taylor (1994) is used to derive and extrapolate the temperature dependence of $R_{\text {eco }}$ :

$R_{\mathrm{eco}}=r_{\mathrm{b}} \exp \left(E_{0}\left(\frac{1}{T_{\mathrm{ref}}-T_{0}}-\frac{1}{T_{\mathrm{obs}}-T_{0}}\right)\right)$

where $r_{\mathrm{b}}\left[\mu \mathrm{mol} \mathrm{C} \mathrm{m}{ }^{-2} \mathrm{~s}^{-1}\right]$ is the base respiration at the reference temperature $T_{\text {ref }}\left[{ }^{\circ} \mathrm{C}\right]$, set to $\left.15^{\circ} \mathrm{C}\right), E_{0}\left[{ }^{\circ} \mathrm{C}\right]$ the temperature sensitivity, $T_{\mathrm{obs}}\left[{ }^{\circ} \mathrm{C}\right]$ is the observed temperature and parameter $T_{0}\left[{ }^{\circ} \mathrm{C}\right]$ is set to $-46.02{ }^{\circ} \mathrm{C}$ as in Lloyd and Taylor (1994). For $E_{0}$ a constant value for each year is derived while $r_{\mathrm{b}}$ was estimated every 5 days using a 15 days window (as in Reichstein et al., 2005). The difference between modelled $R_{\text {eco }}$ and measured NEE yields the estimate for GPP. For this algorithm, the absolute flux magnitude and, therefore, the parameter $r_{\mathrm{b}}$ is mainly determined by the mean nighttime flux.

\subsubsection{Daytime data based estimate}

The daytime data based estimate uses an approach described in detail in Lasslop et al. (2010). It is based on a light response curve extended to account for the temperature sensitivity of respiration by including the Lloyd and Taylor model and a drought limitation of GPP.

$\mathrm{NEE}=-\frac{\alpha \beta R_{\mathrm{g}}}{\alpha R_{\mathrm{g}}+\beta}+r_{\mathrm{b}} \exp \left(E_{0}\left(\frac{1}{T_{\mathrm{ref}}-T_{0}}-\frac{1}{T_{\mathrm{obs}}-T_{0}}\right)\right)$

where $\alpha\left[\mu \mathrm{mol} \mathrm{C} \mathrm{J}^{-1}\right]$ is the canopy light utilisation efficiency and represents the initial slope of the light response curve, $\beta\left[\mu \mathrm{mol} \mathrm{C} \mathrm{m}{ }^{-2} \mathrm{~s}^{-1}\right]$ is the maximum $\mathrm{CO}_{2}$ uptake rate of the canopy at light saturation (see Eq. 4 ), and $R_{\mathrm{g}}$ is the global radiation $\left[\mathrm{W} \mathrm{m}^{-2}\right]$. The limitation of GPP due to high water vapour pressure deficit (VPD) is included by reducing the maximum carbon uptake with an exponential function for VPD values higher than $10 \mathrm{hPa}\left(\mathrm{VPD}_{0}\right)$. The strength of this decrease is determined by the parameter $k$.

$\beta= \begin{cases}\beta_{0} \cdot \exp \left(-k\left(\mathrm{VPD}-\mathrm{VPD}_{0}\right)\right) & \text { if } \mathrm{VPD}>\mathrm{VPD}_{0} \\ \beta_{0} & \text { otherwise }\end{cases}$

$T_{\text {ref }}$ and $T_{0}$ were fixed as in the nighttime data based approach. The parameter $E_{0}$ was estimated using nighttime data of 12 days $\left(R_{\mathrm{g}}<4 \mathrm{~W} \mathrm{~m}^{-2}\right)$, then $E_{0}$ was fixed and $r_{\mathrm{b}}$, $\alpha, \beta$ and $k$ were derived from daytime data using a 4 days window. The estimation was repeated every second day and yields time series of the empirical ecosystem parameters. The $r_{\mathrm{b}}$ parameter is mainly determined by the morning and evening observations as they have the strongest influence in the model range where radiation and, therefore, the contribution of GPP, approaches zero.

\subsection{Statistical analysis}

The correlation between the different temperatures and nighttime NEE was performed for 12 days moving windows. This is the window size that was used in the Lasslop et al. (2010) approach for the estimation of the temperature sensitivity and is similar to the 15 days used in Reichstein et al. (2005), a scale in which the spectra of fluxes show a minimum (Stoy et al., 2009). For each time window we computed the correlation between nighttime NEE and the temperature. We used $T_{\text {air }}, T_{\text {soil }}$, the average of the two, $T_{\text {mean }}, T_{\text {surf }}$ and an optimised temperature $\left(T_{\mathrm{opt}}\right) . T_{\mathrm{opt}}$ was computed as the weighted average of $T_{\text {soil }}$ and $T_{\text {air }}$, with a weight optimised to maximise the correlation with night-time NEE. The weighting factor was allowed to vary between the data windows.

The use of $T_{\mathrm{opt}}$ introduced an additional parameter compared to the use of $T_{\text {air }}$ or $T_{\text {soil }}$. Therefore, for the selection of the temperature driver that best explains the variability of night-time NEE (i.e., the best linear model that relates NEE with $T_{\text {air }}, T_{\text {soil }}$ or $\left.T_{\text {opt }}\right)$ we used the Akaike's Information Criterion (AIC) (Akaike, 1973). AIC is a well-known metric for model selection (Anderson et al., 2000). AIC is a measure of the trade-off between the goodness-of-fit (model explanatory power) and model complexity (number of parameters). Hence, using AIC we can evaluate if the increase in model performance introduced by adding an additional parameter is overcome by an introduction of additional uncertainty.

$\mathrm{AIC}=n \cdot \log (\mathrm{RSS} / n)+2 \cdot(p+1)$

where RSS is the residual sum of squares, $p$ is the number of parameters and $n$ is the sample size. Given a dataset, several competing models (e.g., in our study different models including different temperature drivers, $T_{\text {air }}, T_{\text {soil }}$ and $\left.T_{\text {opt }}\right)$ can be ranked according to their AIC. The model having the lowest AIC is considered the best.

For the flux partitioning the software package PV-Wave (Visual Numerics, 2005) was used. For the statistical analysis the software packages R (R Development Core Team, 2010), and Matlab were used. The lag between the different temperatures was computed by using a cross-correlation function. The time lag was identified when the correlation was at a maximum within a window of $24 \mathrm{~h}$. The degree of dampening was computed as $1 \mathrm{~min}$ the slope of the regression between $T_{\text {air }}$ and $T_{\text {soil }}$. 

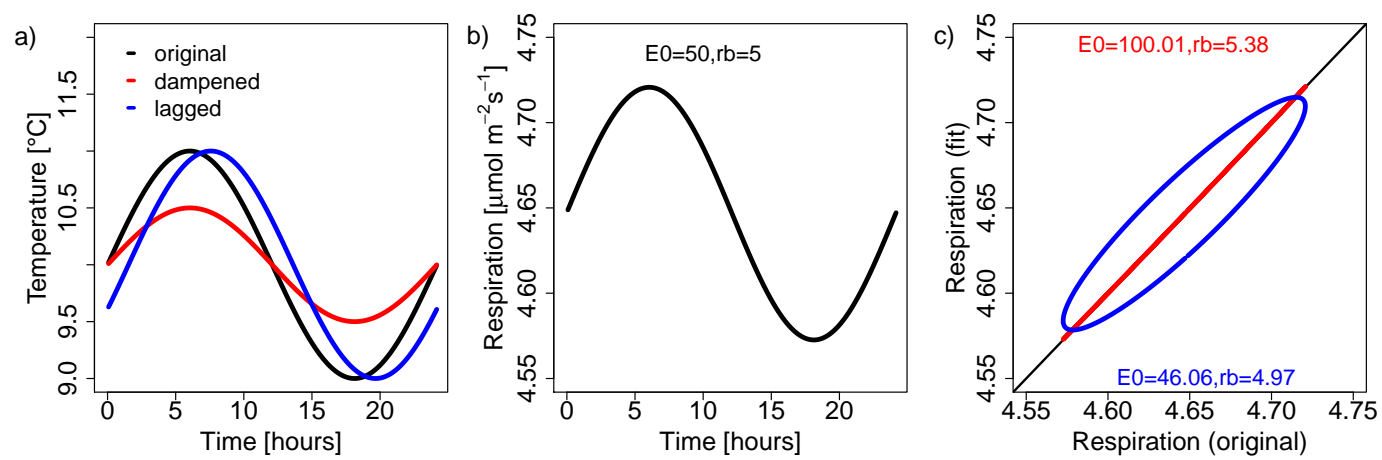

Fig. 1. Illustration of the potential effects of using temperatures that are lagged or dampened on the fit with the respiration model. (a) Artificial temperature time series, (b) respiration model output $\left[\mu \mathrm{mol} \mathrm{C} \mathrm{m}{ }^{-2} \mathrm{~s}^{-1}\right]$ with original (see a) temperature time series and parameter values used, and (c) model output of (b) versus the respiration model outputs optimised for the model output of (b) using the lagged and dampened time series of (a) and optimised parameter values.

\section{Results and discussion}

\subsection{Effects of phase shift and dampening in temperature data on the model fit}

The general understanding of how air temperature relates to soil temperature is that the amplitudes of soil temperature are dampened and its phase is shifted against air temperature due to heat transport processes (Hillel, 2004; Monteith and Unsworth, 1996). Figure 1 shows the effects of dampening and phase shifts on the model fit based on synthetic data. The synthetic respiration rate is the output of the Lloyd and Taylor model driven by the original synthetic temperature time series. If the temperature is only dampened, the two temperatures could still be used as proxies for each other and would only result in different estimates of the temperature sensitivity and base respiration, while the modelled respiration would be almost identical. If the two temperatures are lagged, not only are the parameters affected, but the modelled respiration is lagged (Subke and Bahn, 2010) and the amplitude is decreased.

For most of the FLUXNET sites used here we found a time lag of less than $12 \mathrm{~h}$ (Fig. 2a). The dampening is considerable for most of the sites (Fig. 2b). Due to the frequent occurrence of lags across FLUXNET sites, differences between flux partitioning estimates using one or the other temperature can be expected. As these lags can propagate into the GPP and $R_{\text {eco }}$ estimates, they should be used carefully when exploring lags between $R_{\text {eco }}$ and GPP or between the estimates and environmental drivers. In this analysis the maximum acceptable lag was set to $24 \mathrm{~h}$. Without this limitation only a few sites/years showed a lag longer than $24 \mathrm{~h}$. These were sites/years where temperature was poorly correlated with $R_{\text {eco }}$. This phase shift directly propagates into the flux partitioning estimates. Therefore, there is high uncertainty at the hourly timescale, but more confidence in estimates using aggregated data (i.e., daily or monthly) when
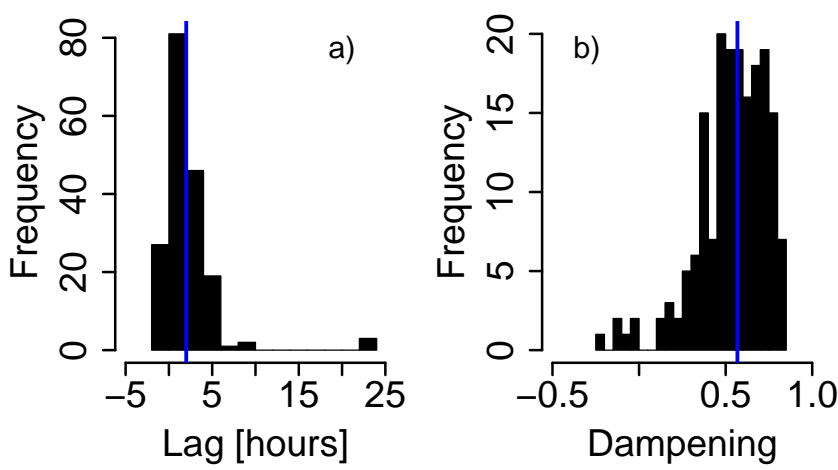

Fig. 2. Histograms of lags (a) and dampening (b) between air and soil temperature (1-slope of the linear regression between the two). Blue vertical lines indicate the median of the distribution. Both lag and dampening was computed using the whole growing season time series. Negative values of the dampening mean the soil temperature has the higher amplitude.

analysing lags or correlations with other fluxes or environmental drivers.

\subsection{Correlation between nighttime NEE and temperature}

During the nighttime, NEE equals ecosystem respiration as photosynthesis is zero in the absence of photosyntheticallyactive radiation (PAR). The linear correlation between nighttime NEE and temperature is a first indication of the explanatory power of temperature as the main driver in a respiration model. Individual temperature data streams cannot perfectly represent the variability of respiration within an ecosystem. In the correlation analysis we tried to identify the temperature that is the best proxy for mapping the variability of the ecosystem respiration.

We compared the median of the correlations within a 12-day time window of nighttime NEE with temperature 


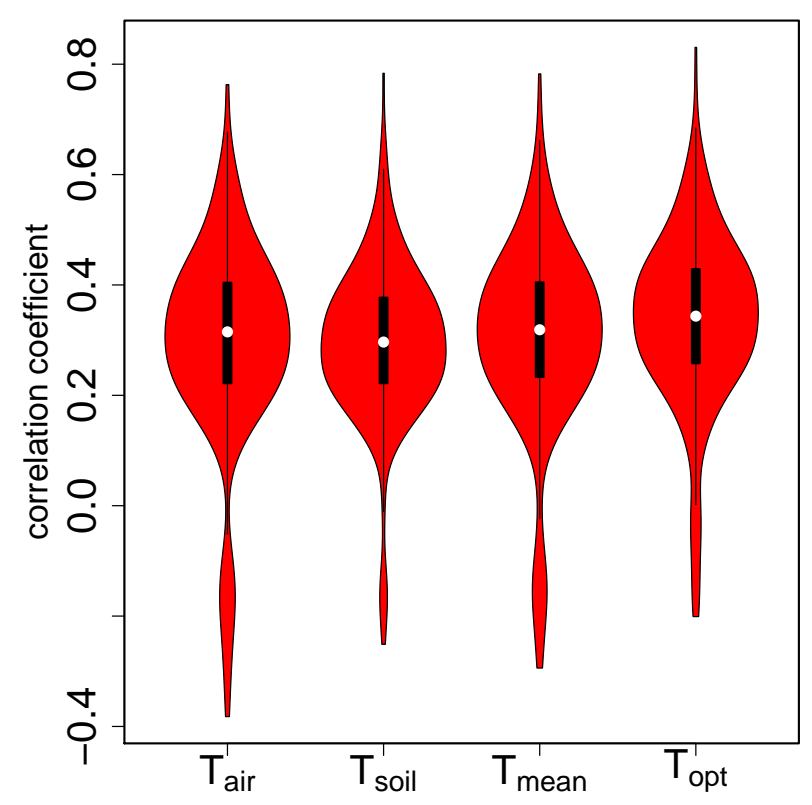

Fig. 3. Correlation with nighttime NEE with $T_{\text {air }}, T_{\text {soil }}$, the average of the two, $T_{\text {mean }}$ and an weighted average with optimised weights, $T_{\text {opt }}$, is computed for 12 days time windows. The violin plot shows the distributions of the median of significant correlations for the growing season of each year across FLUXNET sites, the extent in $\mathrm{x}$-direction indicates the frequency of the $\mathrm{y}$-axis value. The point indicates the median, the thick black line is the interquartile range. The median values are (from left to right) $0.315,0.297,0.319$ and 0.343 .

observations, i.e., $T_{\text {soil }}, T_{\text {air }}$, the average of the two, $T_{\text {mean }}$, and $T_{\mathrm{opt}}$ during the growing season (Fig. 3). $T_{\mathrm{opt}}$ optimises the correlation with a weight parameter. The correlation between nighttime NEE and temperature shows little difference between the different temperature observations. The distribution is bimodal with mostly positive correlations, but negative correlations also exist. All sites with negative correlations either have a subtropical Mediterranean climate or a climate characterised by hot warm summers. This suggests that in these sites the NEE - temperature relationship may be influenced by drought effects. Moisture can affect the relation between NEE and temperature either directly by limiting respiration or by changing the transport processes of heat and $\mathrm{CO}_{2}$. Another reason for negative correlations between NEE and temperature has been revealed by Pilegaard et al. (2011). They found a change of the correlation sign (from positive to negative) during leaf fall related to an increase of substrate availability. Finally, negative correlations could occur due to advection, which can cause problems in eddy covariance nighttime data. For these sites the dynamics of the estimated respiration are not reliable within the 12-day time window as temperature sensitivity is forced to be positive in both algorithms considered here.
Although the difference in the mean correlation between NEE and different temperature streams ( $T_{\text {air }}$ and $\left.T_{\text {soil }}\right)$ is small, we observed a significantly stronger correlation of NEE with $T_{\text {air }}$ when excluding FLUXNET sites with negative correlations. On the other hand, the variability of the correlation coefficients between sites is smaller for $T_{\text {soil }}$. The largest part of ecosystem respiration is soil respiration, which usually contributes more than $60 \%$ (Bolstad et al., 2004; Janssens et al., 2001; Zha et al., 2006), it is, therefore, surprising that the correlation with air temperature is not significantly lower than the correlation with soil temperature. A reason why this is not captured in our correlation analysis might be the variability of temperature in the soil and the lags due to the transport of the respired carbon. During winter the correlation with $T_{\text {soil }}$ is expected to be higher as the vegetation is inactive, and a larger part of the respiration takes place in the soil (Kolari et al., 2009). This seasonal variation of respiration sources could not be identified in the seasonality of the weighting parameter computed for the $T_{\mathrm{opt}}$, which did not show consistent patterns (not shown). The highest median of the correlations across sites with nighttime NEE was observed for the optimised temperature $T_{\text {opt }}$. The optimised temperature includes an additional parameter which also introduces additional uncertainty. In spite of the penalty in the calculation of the AIC score for the additional parameter, the optimised temperature still performs slightly better (median AIC $=53)$ compared to only $T_{\text {soil }}($ median AIC $=60)$ (or only $T_{\text {air }}$ (median AIC $=57$ ) (Fig. 4), as the lower the Akaike criterion, the better the performance.

For a subset of sites, observations of the longwave radiation were available and $T_{\text {surf }}$ could be considered. For this subset of sites, the mean correlation coefficients computed between NEE and different temperature streams were not significantly different. We again observed the $T_{\mathrm{opt}}$ had the greatest correlation with nighttime NEE (median $=0.367$ ). For $T_{\text {mean }}$ the median correlation was 0.346 , followed by $T_{\text {surf }}$ derived from longwave radiation ( 0.339$)$ (no figure). $T_{\text {soil }}$, for this subset, showed a stronger correlation (0.332) than the air temperature (0.325).

For the whole FLUXNET database the correlations do not clearly give advice on which temperature stream is the better proxy for ecosystem respiration. To gain additional insight we analysed the weight parameter of the optimised temperature. To remove the effect of the different variances of soil and air temperature we normalised the temperature time series before computing the weights. The weights for the soil temperature are close to 0.5 , but for a large fraction of the sites $(83 \%)$ the weight is smaller than 0.5 . This indicates that the optimised temperature is slightly stronger influenced by the variability in $T_{\text {air }}$ (Fig. 5) for many sites. For specific vegetation types, using soil temperature could be advantageous as the correlation with soil temperature is higher for deciduous broadleaf forests, for example, while for grasslands or wetlands the correlation is greater with air temperature (see Fig. 6). Strong negative correlations occur less often with 


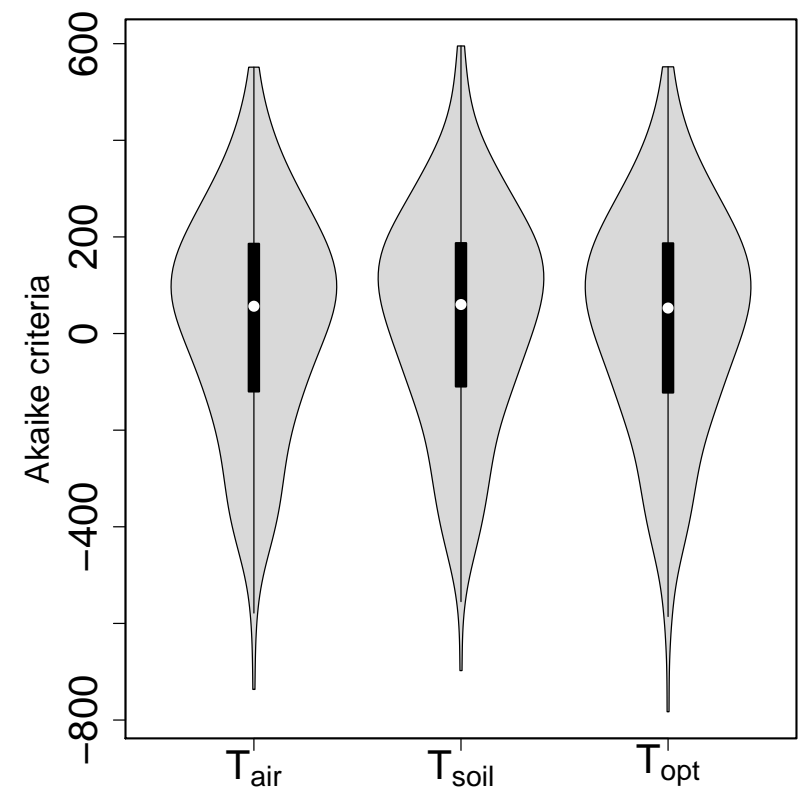

Fig. 4. Median of the Akaike information criterion for 12-days windows with significant correlation with nighttime NEE for all included annual datasets. The point indicates the median, the thick black line is the interquartile range. The median values are (from left to right) $56.6,60.1,52.8$.

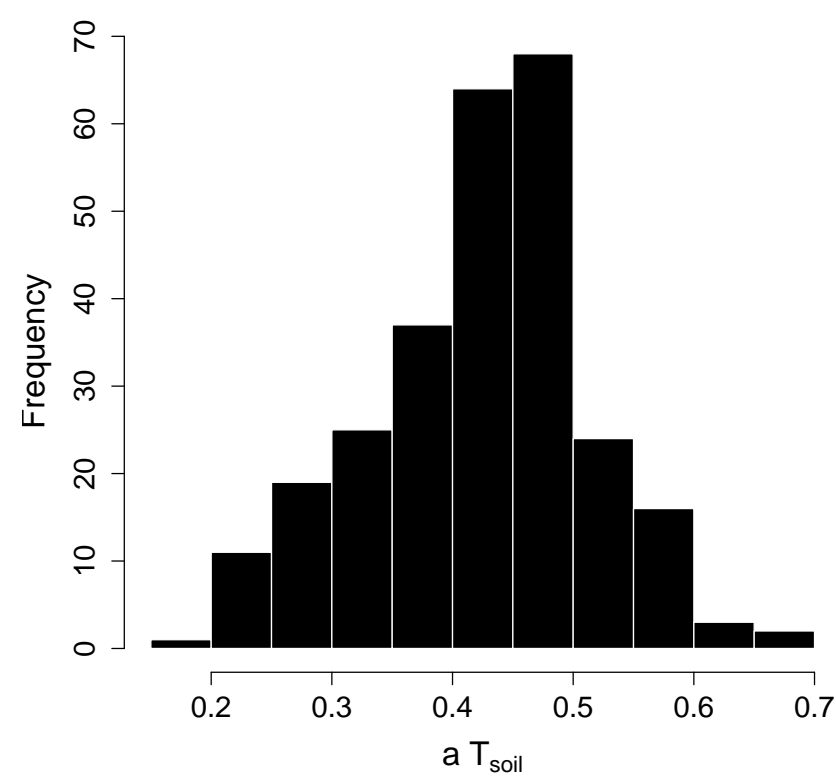

Fig. 5. Median weights of the optimised temperature for the soil part across site and year.

$T_{\text {soil }}$. Overall, the correlation analysis suggests that neither air nor soil temperature is clearly better suited, but analysing the correlation of nighttime NEE with temperature can yield results indicating one is better than the other for specific datasets or sites. The higher or lower correlations cannot be interpreted as there being a greater or lesser contribution of

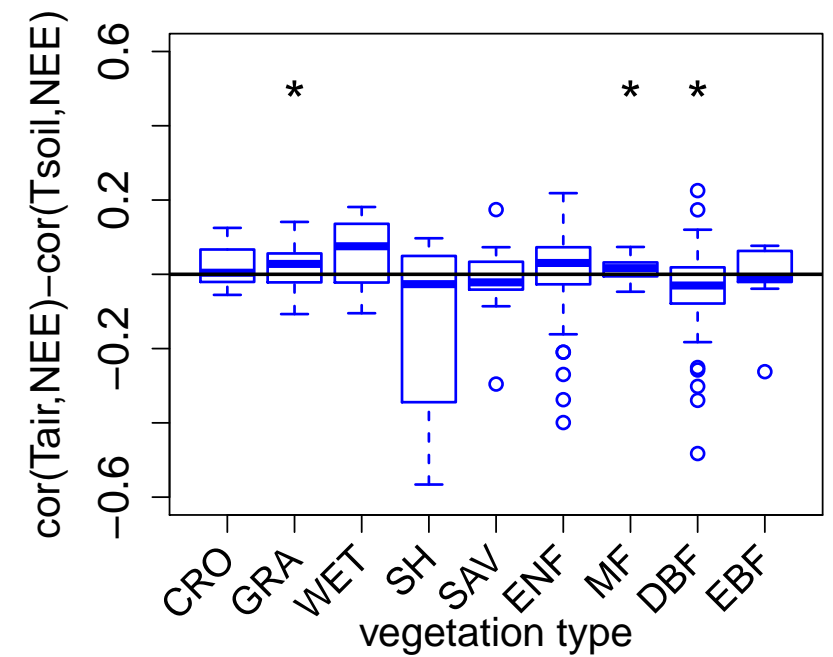

Fig. 6. Differences between the median of significant correlations with air and soil temperature with nighttime NEE for the growing season of one year across FLUXNET sites for different vegetation types. CRO: crops, DBF: deciduous broadleaf forest, EBF: evergreen broadleaf forest, ENF: evergreen needleleaf forest, GRA: grassland, MF: mixed forest, SAV: savanna, SH: shrubs, WET: wetland. The asterisk indicates significance.

the one or other ecosystem component to the total flux. However, in flux partitioning or gap filling procedures the temperature which explains more of the variability in an eddycovariance time series should be considered the most useful.

Soil is a very heterogeneous part of the ecosystem; the representativeness of soil measurements can be a limiting factor and it might depend on the number and position of soil temperature sensors. We performed an additional correlation analysis for one site, Hyytiälä, where observations of soil temperature at five observation depths at five locations around the tower were provided. The analysis showed that the correlation between temperature and nighttime NEE decreases on average with increasing observation depth (see Fig. 7). The differences between the correlations at the first two depths are already statistically significant $(p=0.03)$. This supports our decision to always use the upper soil temperature observation and emphasises the importance of measurements in the very top layer $(2 \mathrm{~cm})$. For many sites the uppermost soil temperature is measured at $5 \mathrm{~cm}$ depth (see Table 1). As the measurement depth is not completely harmonised within FLUXNET, differences in the soil temperature measurement depth can explain part of the spread of the correlations between nighttime NEE and temperature across sites. The correlations of temperature measurements with nighttime NEE from different locations (at a similar depth) are very similar in their magnitude and variability (see Fig. 7b). Representativeness of the soil temperature measurements is, therefore, not a critical issue at this site. 

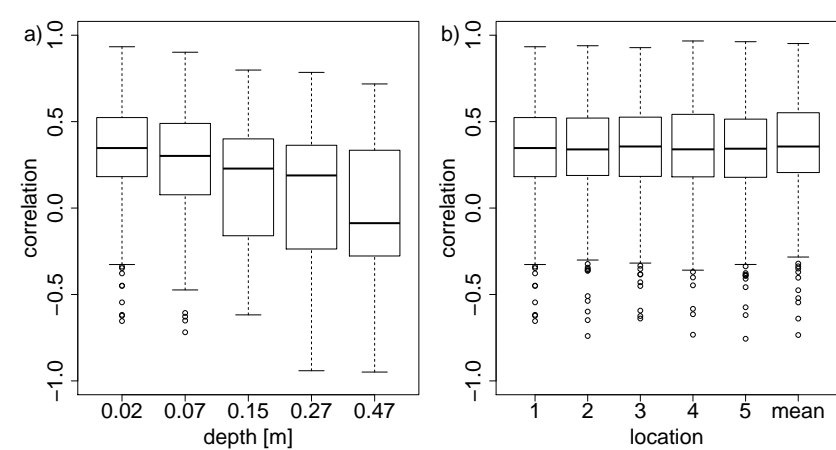

Fig. 7. Correlations between temperature and nighttime NEE at the Finish station Hyytiälä, based on temperature measurements in 5 depths (a) and the top measurement $(0.02 \mathrm{~m})$ at 5 locations (b).

\subsection{Difference in flux components derived using air and soil temperature}

Both flux partitioning algorithms were run for the FLUXNET data using either air or soil temperature. When comparing the median of the differences in the annual estimates of the flux components derived with air or soil temperature the two algorithms applied differ: for the Lasslop et al. (2010) approach only the median of the differences in GPP estimates across FLUXNET sites differed significantly from zero (median $=-23.8 \mathrm{~g} \mathrm{C} \mathrm{m}^{-2} \mathrm{yr}^{-1}$ ), for the Reichstein et al. (2005) approach both flux components showed a small median difference of $\approx-26.7 \mathrm{~g} \mathrm{C} \mathrm{m}^{-2} \mathrm{yr}^{-1}$ (Fig. 8). The estimates using $T_{\text {air }}$ were higher. The differences are the same for Reco and GPP for the Reichstein et al. (2005) approach, because GPP is computed as the residuum. The estimates of the two flux partitioning algorithms were compared in a previous study (Lasslop et al., 2010). The range of these deviations due to the choice of the algorithm were about twice as high as the differences found here due to the choice of the temperature observations. However, the mean difference between the two algorithms in this previous study was not significant across the FLUXNET sites.

These GPP datasets were the basis for global estimates derived by upscaling eddy covariance data to global gridded estimates. Assuming a constant bias of $25 \mathrm{~g} \mathrm{C} \mathrm{m}^{-2} \mathrm{yr}^{-1}$ for all sites a rough estimate for the effect of the choice of the temperature stream can be estimated as $3.2 \mathrm{PgC}^{-1}$ for the global GPP of $123 \mathrm{Pg} \mathrm{C} \mathrm{yr}^{-1}$ (Beer et al., 2010) (value was obtained by multiplying the $25 \mathrm{~g} \mathrm{C} \mathrm{m}^{-2} \mathrm{yr}^{-1}$ with the global vegetated area). This is a conservative estimate as one would expect that the true value is between the two estimates while $25 \mathrm{~g} \mathrm{C} \mathrm{m}^{-2} \mathrm{yr}^{-1}$ is the average difference.

The average diurnal cycles of $R_{\text {eco }}$ and GPP derived with the two partitioning algorithms were further analysed. For the Lasslop et al. (2010) approach the positive differences of $R_{\text {eco }}$ during nighttime and the negative differences during daytime cancelled out. This can explain why the differences in the annual totals were close to zero. The GPP differences of the same approach were zero at night as GPP is forced to be zero with the light response curve. During day the differences were negative on average and summed up (Fig. 9), here the differences in Reco propagate into the GPP estimate as the difference between the two is fit to the observed NEE. For the Reichstein et al. (2005) approach the residuals for both estimates were zero on average during night and the mostly negative differences during daytime summed up and caused the difference in the annual estimates. The methodological difference between the algorithms that can explain this effect is the estimation of the base respiration parameter $\left(r_{\mathrm{b}}\right)$, that determines the flux magnitude at the reference temperature $\left(T_{\text {ref }}\right)$ as described in Eq. (2) and (3). The nighttime based approach fits this parameter with all the nighttime data and ensures a mean respiration during nighttime that equals mean observed nighttime NEE using both temperatures. For the daytime based approach this parameter is most strongly determined by morning and evening observations. During morning and evening hours the temperature is closer to the mean temperature, while the nighttime values are lower than the mean daily temperature. Thus, the temperature sensitivity parameter of the nighttime data based approach is used to extrapolate only to higher temperatures while the flux magnitude is fixed such that the mean nighttime flux equals the respiration flux during night. For the daytime databased approach where the respiration flux magnitude is mainly determined by the morning and evening values and the algorithm relies on the temperature sensitivity estimate to compute fluxes with lower temperature during night, but also for higher temperatures during daytime. Thus, in this approach when a bias in the temperature sensitivity parameter occurs, the errors during the cooler night can be cancelled out by estimates for the warmer day. On the other hand observations during morning and evening have a high relative uncertainty (absolute uncertainty/flux magnitude), and can be an explanation for the higher MAD of the differences in annual $R_{\text {eco }}$ (Fig. 8) and the higher spread of the differenced diurnal cycle. The half hourly values of the averaged diurnal cycle show differences up to $1.5 \mu \mathrm{mol} \mathrm{C} \mathrm{m}{ }^{-2} \mathrm{~s}^{-1}$ between the soil and air temperature estimate which is consistent with other studies (Kolari et al., 2009; Ibrom et al., 2006).

\subsection{Inter site patterns in the difference of the estimates}

Here we analysed whether parameters that are related to the decoupling of soil and atmosphere can explain the variability of the effect that the choice of temperature has on the result of the flux partitioning algorithm. As the algorithms are exactly the same and only the temperature input is changing, the relationship between air and soil temperature could be an indicator for the magnitude of the difference. To characterise the relationship between air and soil temperature we used the lag between the two. The relation between the differences 

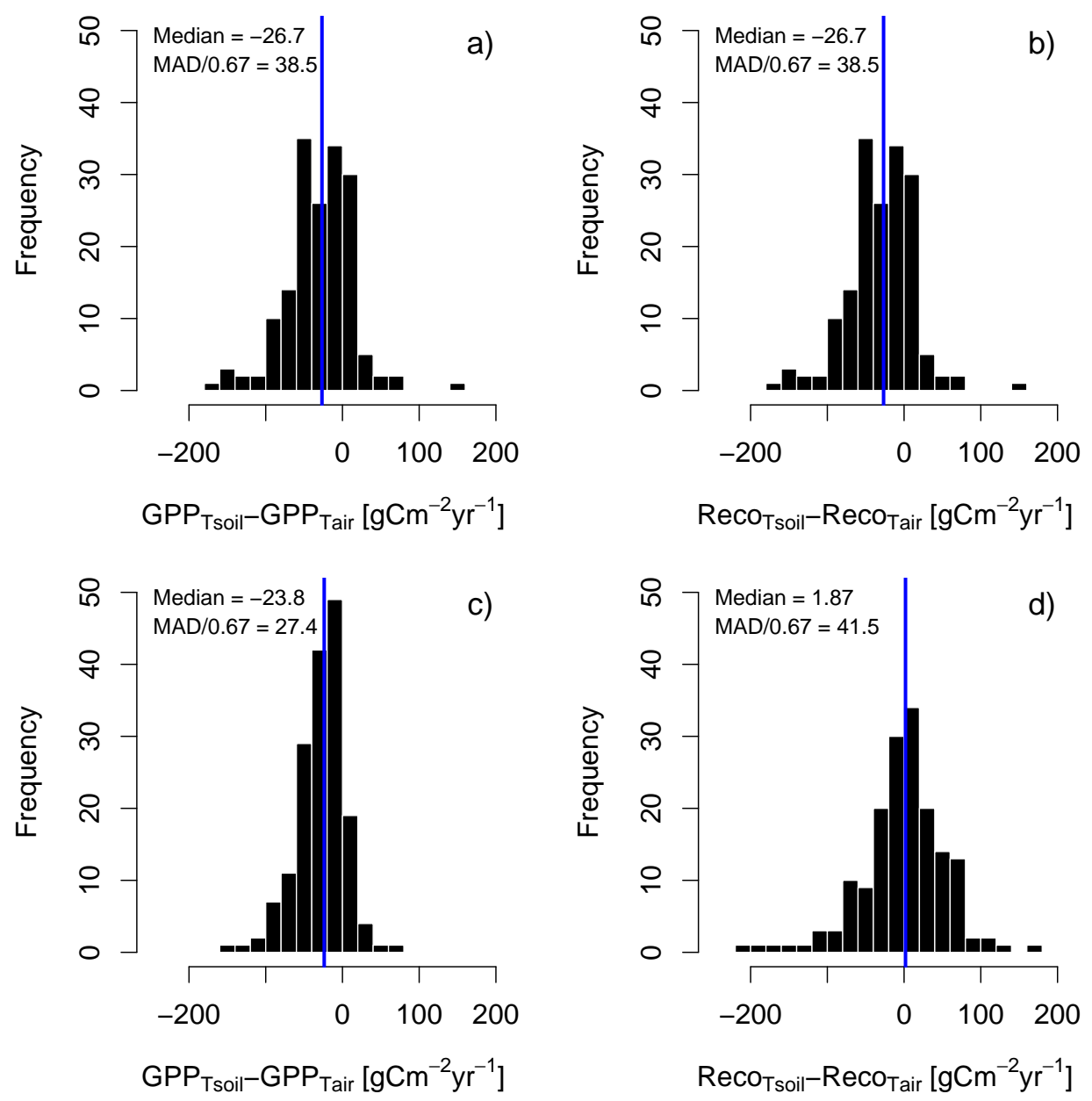

Fig. 8. Difference in annual estimates using the Reichstein et al. (2005) method (a), (b) and the Lasslop et al. (2010) approach (c), (d), blue vertical line indicates the median value, MAD is the median absolute deviation. Note that (a) and (b) are identical due to the methodology.

and the temperature lag was stronger for the nighttime based method (Fig. 10). The correlation was less significant for the daytime based method. The relationship for the daytime data based $R_{\text {eco }}$ was of opposite direction. The flux components of the daytime based method are less strongly related as GPP is not computed as the residual, but is based on the light response. Including this additional model seems to make the method less prone to biases. Other indicators for the strength of the decoupling between soil and air temperatures are the maximum LAI $\left(\mathrm{LAI}_{\max }\right)$ of the site and the soil organic carbon content (SOC). A high LAI decouples air and soil processes and dampens the soil temperature (Zheng et al., 1993), while a very low LAI and direct insulation on the ground can heat up the soil faster than the surrounding air. Soil organic carbon has a low heat conductivity and high heat capacity, which can increase the lag between air and soil temperature. Therefore, we would expect a correlation between values of $\mathrm{LAI}_{\max }$ or SOC and the differences in GPP and $R_{\text {eco }}$ due to the choice of the temperature stream. The correlation be- tween $\mathrm{LAI}_{\max }$ was of similar magnitude as for the temperature lag (Fig. 11). For the SOC the correlation was not significant (not shown). Unfortunately the high heterogeneity of the soil and the not fully harmonised measurement protocols hamper the comparison across sites and might obscure existing patterns.

When separating the differences into vegetation types, we found a general tendency for the difference to increase with increasing vegetation height (see Fig. 12). The pattern was less clear for the Lasslop et al. (2010) approach.

\subsection{Influence on ecosystem parameters}

As eddy-covariance data are increasingly used to derive ecosystem parameters or to constrain and evaluate process based land surface models for the water and carbon cycle (Bonan et al., 2011; Knorr and Kattge, 2005; Mahecha et al., 2010; Reichstein et al., 2003b), we analysed the effects of the choice of temperature for three ecosystem parameters: 

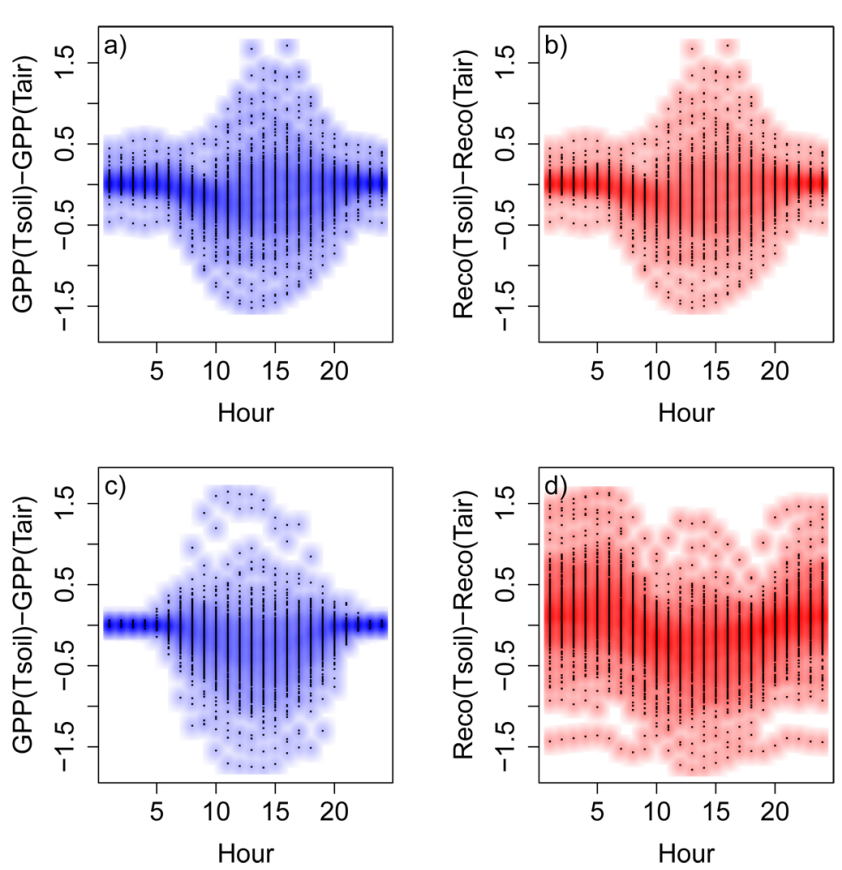

Fig. 9. Mean diurnal cycle of differences $\left[\mu \mathrm{mol} \mathrm{Cm}^{-2} \mathrm{~s}^{-1}\right]$ between the estimates using soil and air temperature, averaged over the growing season for the Reichstein et al. (2005) (a), (b) and for the Lasslop et al. (2010) approach (c), (d).

temperature sensitivity of ecosystem respiration, base respiration and maximum carbon uptake rate. The largest differences were found for the temperature sensitivity (Fig. 13). Because the variance is higher for air temperature than for soil temperature it yields lower estimates for the temperature sensitivity when fitted to the same NEE data. In the short term, a lower temperature sensitivity estimated for air temperature would be compensated by the higher variability of the air temperature, as in the case of the flux partitioning. When a temperature sensitivity estimate is to be used in another model, the driving temperature needs to have a similar variability. A sensitivity parameter estimated with air temperature should not be used for a model driven by soil temperature (Mahecha et al., 2011; Graf et al., 2011). Avoiding biases in the long term might be more problematic as it will increase both temperatures, air and soil, in a similar way. Thus, extrapolating this parameter to other time scales, for instance by including this parameter in a process based model for the use in climate projections, requires caution. The base respiration is significantly higher for soil temperature, which might be due to a parameter correlation of the base respiration with the temperature sensitivity. The sign of the difference depends on the relation between the mean of the temperature observations used and the reference temperature. It can be minimised by setting the reference temperature to the mean observed temperature.
The maximum carbon uptake rate value was lower with the soil temperature estimate, as the GPP estimate computed using soil temperature was lower. This should be considered when optimising or evaluating models with estimates derived with the algorithms presented here.

\section{Conclusions}

In this study, we analysed the uncertainty of GPP and $R_{\text {eco }}$ estimates caused by the choice between air or soil temperature observations using two commonly used flux partitioning algorithms. The correlation analysis showed that the linear correlation between the different temperature observations and nighttime NEE was similar. However, the correlation with air temperature was slightly but significantly higher across FLUXNET sites. For specifically selected sites soil temperature can explain more of the nighttime NEE variation. The highest performance was achieved with an averaged temperature with optimised weights, in spite of the cost of having an additional parameter. We recommend sitespecific evaluations to determine which temperature explains most of the variability of the ecosystem respiration (nighttime NEE). As surface temperature showed a good correlation with nighttime NEE, observations of longwave radiation or surface temperature could be a useful extension of the measurements at flux sites.

The differences in $R_{\text {eco }}$ and GPP estimates using the Reichstein et al. (2005) method are generally the same because GPP is simply the difference between $R_{\text {eco }}$ and NEE. On the annual time scale they show an average difference of $26 \mathrm{~g} \mathrm{C} \mathrm{m}^{-2} \mathrm{yr}^{-1}$. The median of deviations for GPP based on Lasslop et al. (2010) is slightly smaller, and for $R_{\text {eco }}$ it is close to zero. The reason could be revealed by analysing the mean diurnal cycles: for the $R_{\text {eco }}$ of the Lasslop et al. (2010) method nighttime differences are cancelled out by differences during daytime. An estimate of the potential bias, i.e., the difference owing to the choice of temperature, for the global upscaling of eddy-covariance GPP is $3.2 \mathrm{Pg} \mathrm{C}$ per year assuming a constant difference of $25 \mathrm{~g} \mathrm{C} \mathrm{m}^{-2} \mathrm{yr}^{-1}$ for the vegetated land surface.

The intersite pattern of annual differences can be partly explained by the vegetation structure (e.g., vegetation types, lag between temperatures). The time lag between soil and air temperature was the best indicator for the difference between the estimate using soil or air temperature, respectively.

The strongest influence of the choice of the temperature observations for the ecosystem parameter values was on the temperature sensitivity, but all parameters showed a significant difference across sites.

At our current level of understanding of the magnitude of uncertainties in flux partitioning algorithms, we recommend using both soil and air temperature as drivers for partitioning algorithms and including both datasets to account for the uncertainty due to the choice of temperature. 

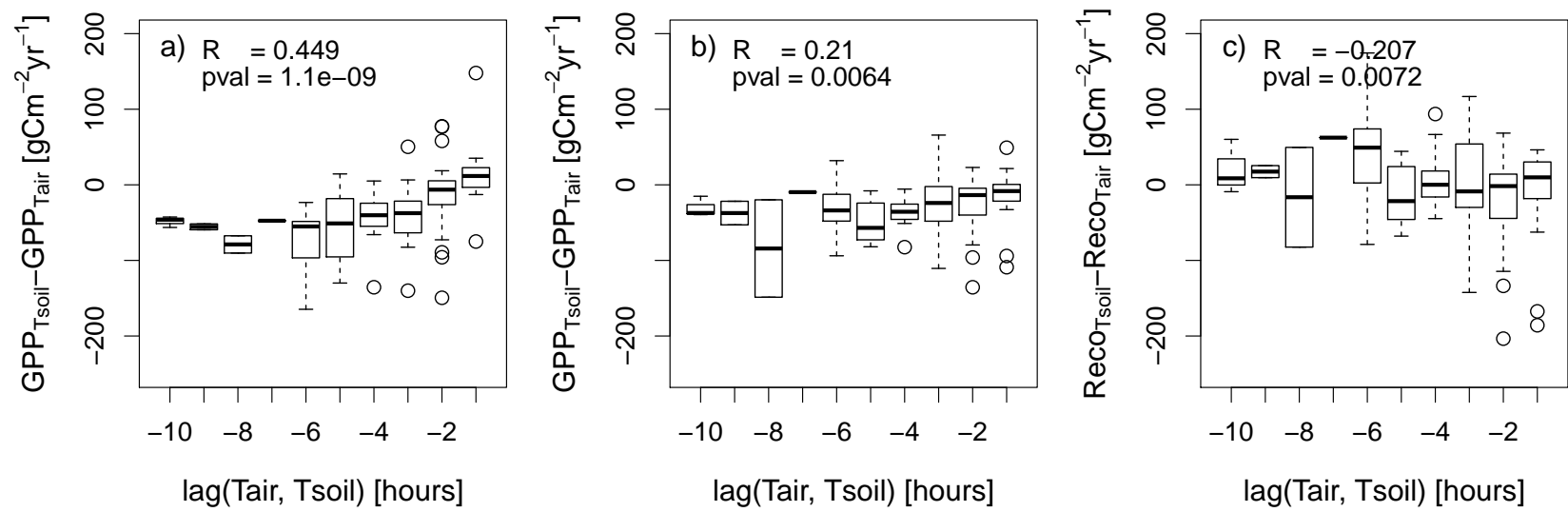

Fig. 10. Annual differences between the carbon fluxes estimated with soil and air temperature versus lag between air and soil temperature for the Reichstein et al. (2005) (a) and Lasslop et al. (2010) (b), (c) approach. Note that for the Reichstein et al. (2005) approach results are the same for both components.
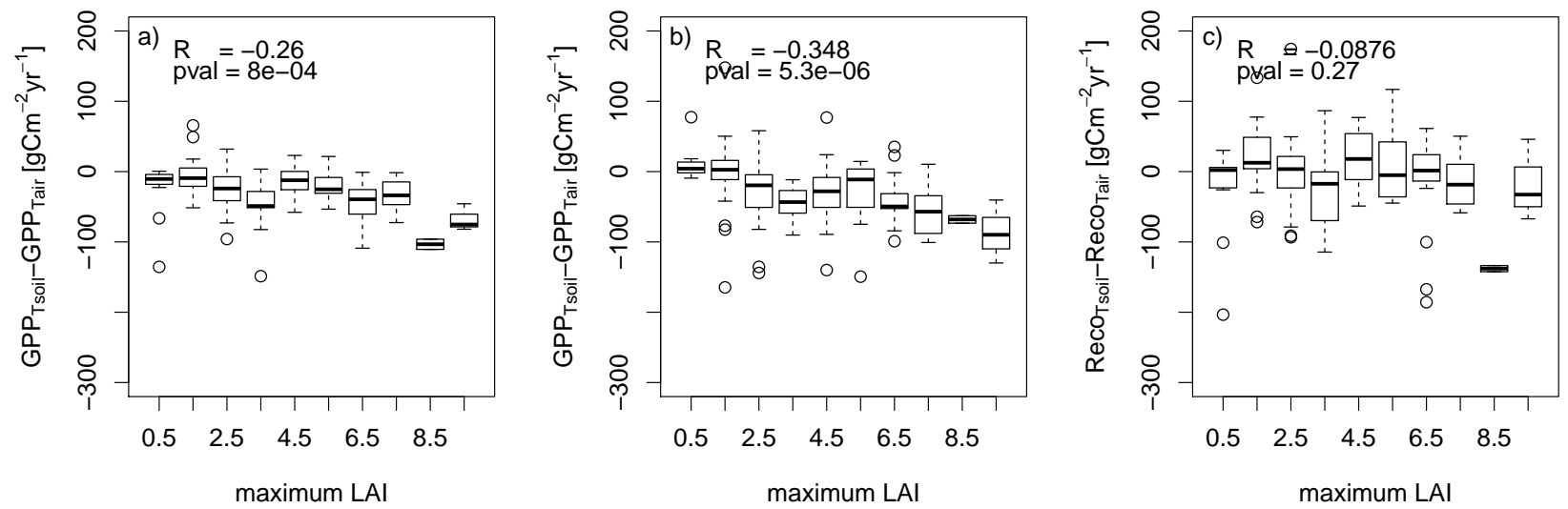

Fig. 11. Difference in annual GPP estimates using the Reichstein et al. (2005) approach (a) (note that for the $R_{\text {eco }}$ estimates the plot would be exactly the same) and in annual GPP (b) and $R_{\text {eco }}$ (c) estimates using the Lasslop et al. (2010) approach versus the maximum LAI measured at the site.
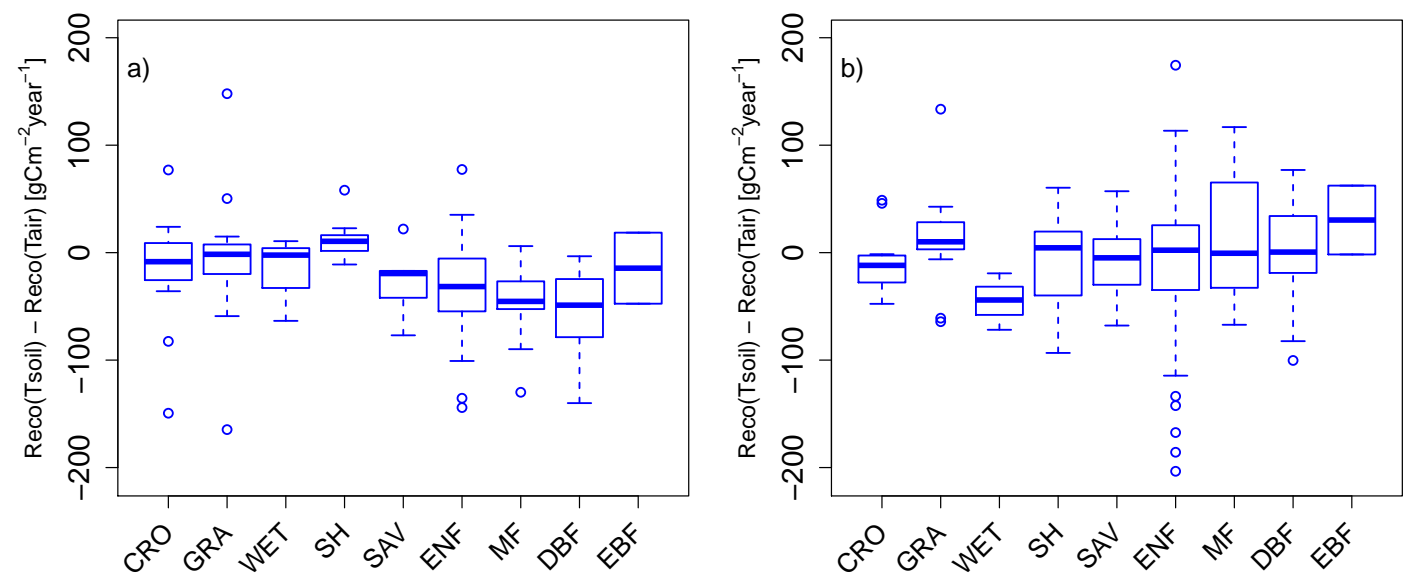

Fig. 12. Difference in annual $R_{\text {eco }}$ estimates using the Reichstein et al. (2005) approach (a) and the Lasslop et al. (2010) approach (b), distinguished according to vegetation types (see Fig. 5 for vegetation types definition). 

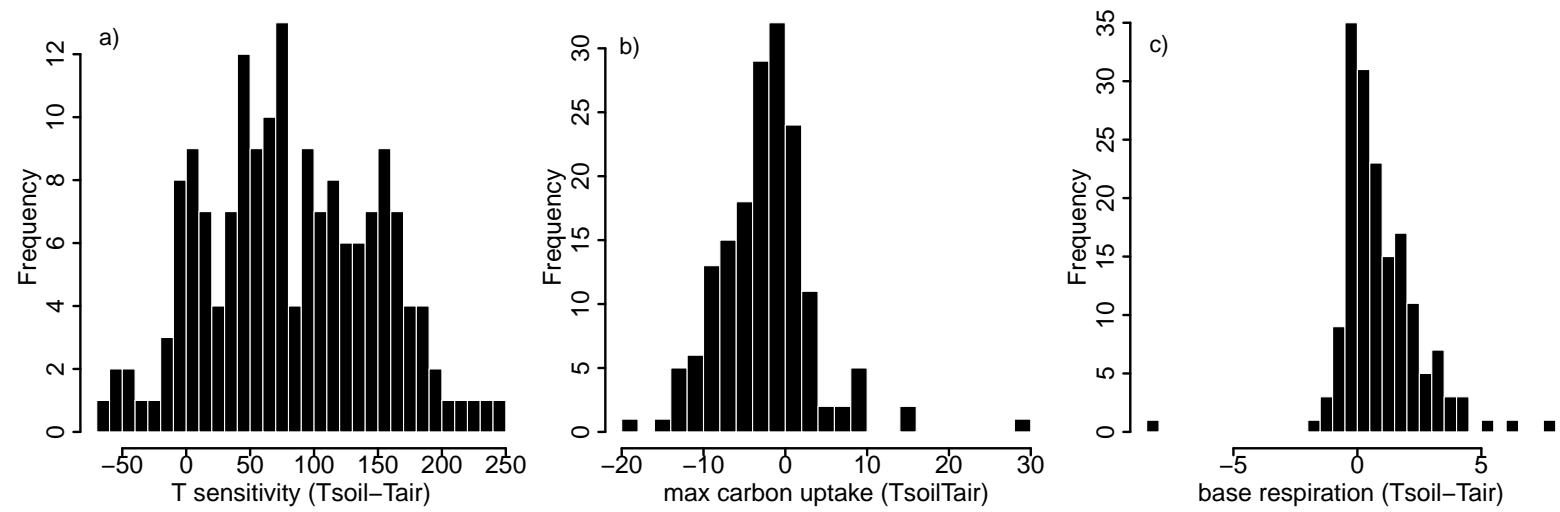

Fig. 13. Differences in the estimates of the temperature sensitivity $\left[{ }^{\circ} \mathrm{C}\right](\mathbf{a})$, maximum carbon uptake rate $\left[\mu \mathrm{mol} \mathrm{C} \mathrm{m}^{-2} \mathrm{~s}^{-1}\right](\mathbf{b})$ and base respiration $\left[\mu \mathrm{mol} \mathrm{C} \mathrm{m} \mathrm{C}^{-2} \mathrm{~s}^{-1}\right.$ ) (c) using soil and air temperature across FLUXNET sites. The histogram shows the differences of the parameters derived with air and soil temperature across FLUXNET sites.

Acknowledgements. We thank the FLUXNET site PIs for contributing data, the agencies and institutions that funded these long-term measurements, and the regional networks AmeriFlux, Afriflux, Asiaflux, CarboEurope-IP, ChinaFlux, Fluxnet-Canada, KoFlux, LBA, NECC, OzFlux, TCOS-Siberia, USCCC. This project resulted from the 2007 La Thuile FLUXNET workshop, which would not have been possible without the financial support provided by CarboEuropeIP, FAO-GTOS-TCO, iLEAPS, Max Planck Institute for Biogeochemistry, National Science Foundation, University of Tuscia, US Department of Energy. Moreover, we acknowledge databasing and technical support from Berkeley Water Centre, Lawrence Berkeley National Laboratory, Microsoft Research eScience, Oak Ridge National Laboratory, University of California-Berkeley and University of Virginia. The Metolius AmeriFlux research was supported by the Office of Science (BER), US Department of Energy, Grant No. DE-FG02-06ER64318. The research at US-Var was supported in part by the Office of Science (BER), US Department of Energy, Grant No. DE-FG0203ER63638. GL acknowledges funding from the FP7 project CARBONES. GB and the UMBS site were funded by NSF DEB 0911461; US DoE DE-SC0006708; NOAA NA11OAR4310190.

\section{Edited by: N. Saigusa}

The service charges for this open access publication have been covered by the Max Planck Society.

\section{References}

Akaike, H.: Information theory and an extention of the maximum likelihood principle, 2nd International Symposium on Information Theory, 267-281, http://citeseerx.ist.psu.edu/viewdoc/ summary?doi=10.1.1.55.71\%81, 1973.

Allison, V. J., Miller, R. M., Jastrow, J. D., Matamala, R., and Zak, D. R.: Changes in soil microbial community structure in a tallgrass prairie chronosequence, Soil Sci. Soc. Am. J., 69, 1412 1421, 2005

Anderson, D., Burnham, K., and Thompson, W.: Null hypothesis testing: problems, prevalence, and an alternative, J. Wildlife
Manage., 64, 912-923, 2000.

Anthoni, P. M., Knohl, A., Rebmann, C., Freibauer, A., Mund, M., Ziegler, W., Kolle, O., and Schulze, E. D.: Forest and agricultural land-use-dependent $\mathrm{CO}_{2}$ exchange in Thuringia, Germany, Glob. Change Biol., 10, 2005-2019, 2004.

Arain, M. A. and Restrepo-Coupe, N.: Net ecosystem production in a temperate pine plantation in southeastern Canada, Agr. Forest Meteorol., 128, 223-241, 2005.

Aubinet, M., Chermanne, B., Vandenhaute, M., Longdoz, B., Yernaux, M., and Laitat, E.: Long term carbon dioxide exchange above a mixed forest in the Belgian Ardennes, Agr. Forest Meteorol., 108, 293-315, 2001.

Aurela, M., Riutta, T., Laurila, T., Tuovinen, J. P., Vesala, T., Tuittila, E. S., Rinne, J., Haapanala, S., and Laine, J.: $\mathrm{CO}_{2}$ exchange of a sedge fen in southern Finland - The impact of a drought period, Tellus B, 59, 826-837, 2007.

Beer, C., Reichstein, M., Tomelleri, E., Ciais, P., Jung, M., Carvalhais, N., Rodenbeck, C., Arain, M. A., Baldocchi, D., Bondeau, G. B. B. A., Cescatti, A., Lasslop, G., Lindroth, A., Lomas, M., Luyssaert, S., Margolis, H., Oleson, K. W., Roupsard, O., Veenendaal, E., Viovy, N., Williams, ,C., Woodward, F. I., and Papale, D.: Terrestrial Gross Carbon Dioxide Uptake: Global Distribution and Covariation with Climate, Science, 329, 834-838, doi:10.1126/science.1184984, 2010.

Bergeron, O., Margolis, H., Black, T., Coursolle, C., Dunn, A., Barr, A., and Wofsy, S.: Comparison of carbon fluxes over three boreal black spruce forests in Canada, Glob. Change Biol., 13, 89-107, 2007.

Black, T. A., Chen, W. J., Barr, A. G., Arain, M. A., Chen, Z., Nesic, Z., Hogg, E. H., Neumann, H. H., and Yang, P. C.: Increased carbon sequestration by a boreal deciduous forest in years with a warm spring, Geophys. Res. Lett., 27, 1271-1274, 2000.

Bolstad, P., Davis, K., Martin, J., Cook, B., and Wang, W.: Component and whole-system respiration fluxes in northern deciduous forests, Tree Physiol., 24, 493-504, 2004.

Bonan, G. B., Lawrence, P. J., Oleson, K. W., Levis, S., Jung, M., Reichstein, M., Lawrence, D. M., and Swenson, S. C.: Improving canopy processes in the Community Land Model version 4 (CLM4) using global flux fields empirically in- 
ferred from FLUXNET data, J. Geophys. Res., 116, G02014, doi:10.1029/2010JG001593, 2011.

Bracho, R., Starr, G., Gholz, H., Martin, T., Cropper Jr., W., and Loescher, H.: Controls on carbon dynamics by ecosystem structure and climate for southeastern US slash pine plantations, Ecol. Monographs, 82, 101-128, 2012.

Chiesi, M., Maselli, F., Bindi, M., Fibbi, L., Cherubini, P., Arlotta, E., Tirone, G., Matteucci, G., and Seufert, G.: Modelling carbon budget of Mediterranean forests using ground and remote sensing measurements, Agr. Forest Meteorol., 135, 22-34, 2005.

Cook, B. D., Davis, K. J., Wang, W. G., Desai, A., Berger, B. W., Teclaw, R. M., Martin, J. G., Bolstad, P. V., Bakwin, P. S., Yi, C. X., and Heilman, W.: Carbon exchange and venting anomalies in an upland deciduous forest in northern Wisconsin, USA, Agr. Forest Meteorol., 126, 271-295, 2004.

Davis, K. J., Bakwin, P. S., Yi, C. X., Berger, B. W., Zhao, C. L., Teclaw, R. M., and Isebrands, J. G.: The annual cycles of $\mathrm{CO}_{2}$ and $\mathrm{H}_{2} \mathrm{O}$ exchange over a northern mixed forest as observed from a very tall tower, Glob. Change Biol., 9, 1278-1293, 2003.

Desai, A. R., Richardson, A. D., Moffat, A. M., Kattge, J., Hollinger, D. Y., Barr, A., Falge, E., Noormets, A., Papale, D., Reichstein, M., and Stauch, V. J.: Cross-site evaluation of eddy covariance GPP and RE decomposition techniques, Agr. Forest Meteorol., 148, 821-838, 2008.

Elbers, J. A., Jacobs, C. M. J., Kruijt, B., Jans, W. W. P., and Moors, E. J.: Assessing the uncertainty of estimated annual totals of net ecosystem productivity: a practical approach applied to a midlatitude temperate pine forest, Agr. Forest Meteorol., 151, 18231830, 2011.

Falge, E., Baldocchi, D., Tenhunen, J., Aubinet, M., Bakwin, P., Berbigier, P., Bernhofer, C., Burba, G., Clement, R., Davis, K. J., Elbers, J. A., Goldstein, A. H., Grelle, A., Granier, A., Guomundsson, J., Hollinger, D., Kowalski, A. S., Katul, G., Law, B. E., Malhi, Y., Meyers, T., Monson, R. K., Munger, J. W., Oechel, W., Paw, K. T., Pilegaard, K., Rannik, Ü., Rebmann, C., Suyker, A., Valentini, R., Wilson, K., and Wofsy, S.: Seasonality of ecosystem respiration and gross primary production as derived from FLUXNET measurements, Agr. Forest Meteorol., 113, 5374, 2002.

Fischer, M. L., Billesbach, D. P., Berry, J. A., Riley, W. J., and Torn, M. S.: Spatiotemporal variations in growing season exchanges of $\mathrm{CO}_{2}, \mathrm{H}_{2} \mathrm{O}$, and sensible heat in agricultural fields of the Southern Great Plains, Earth Interact., 11, 1-21, 2007.

Flanagan, L. B., Wever, L. A., and Carlson, P. J.: Seasonal and interannual variation in carbon dioxide exchange and carbon balance in a northern temperate grassland, Glob. Change Biol., 8, 599615, 2002.

Garbulsky, M. F., Penuelas, J., Papale, D., and Filella, I.: Remote estimation of carbon dioxide uptake by a Mediterranean forest, Glob. Change Biol., 14, 2860-2867, 2008.

Giasson, M.-A., Coursolle, C., and Margolis, H.: Ecosystem-level carbon fluxe from a boreal cutover in eastern Canada before and after scarification, Agr. Forest Meteorol., 140, 23-40, 2006.

Gilmanov, T. G., Tieszen, L. L., Wylie, B. K., Flanagan, L. B., Frank, A. B., Haferkamp, M. R., Meyers, T. P., and Morgan, J. A.: Integration of $\mathrm{CO}_{2}$ flux and remotely-sensed data for primary production and ecosystem respiration analyses in the Northern Great Plains: potential for quantitative spatial extrapolation, Global Ecol. Biogeogr., 14, 271-292, 2005.
Gilmanov, T. G., Soussana, J. E., Aires, L., Allard, V., Ammann, C., Balzarolo, M., Barcza, Z., Bernhofer, C., Campbell, C. L., Cernusca, A., Cescatti, A., Clifton-Brown, J., Dirks, B. O. M., Dore, S., Eugster, W., Fuhrer, J., Gimeno, C., Grünwald, T., Haszpra, L., Hensen, A., Ibrom, A., Jacobs, A. F. G., Jones, M. B., Lanigan, G., Laurila, T., Lohila, A., Manca, G., Marcolla, B., Nagy, Z., Pilegaard, K., Pinter, K., Pio, C., Raschi, A., Rogiers, N., Sanz, M. J., Stefani, P., Sutton, M., Tuba, Z., Valentini, R., Williams, M. L., and Wohlfahrt, G.: Partitioning European grassland net ecosystem $\mathrm{CO}_{2}$ exchange into gross primary productivity and ecosystem respiration using light response function analysis, Agr. Ecosy. Environ., 121, 93-120, 2007.

Graf, A., Weihermueller, L., Huisman, J. A., Herbst, M., and Vereecken, H.: Comment on Global convergence in the temperature sensitivity of respiration at ecosystem level, Science, 331, p. 1265, doi:10.1126/science.1196948, 2011.

Granier, A., Ceschia, E., Damesin, C., Dufrłne, E., Epron, D., Gross, P., Lebaube, S., Dantec, V. L., Goff, N. L., Lemoine, D., Lucot, E., Ottorini, J. M., Pontailler, J. Y., and Saugier, B.: The carbon balance of a young Beech forest, Funct. Ecol., 14, 312-325, 2000.

Grünwald, T. and Bernhofer, C.: A decade of carbon, water and energy flux measurement of an old spruce forest at the Anchor Station Tharandt, Tellus B, 59, 387-396, 2007.

Gu, L. H., Meyers, T., Pallardy, S. G., Hanson, P. J., Yang, B., Heuer, M., Hosman, K. P., Riggs, J. S., Sluss, D., and Wullschleger, S. D.: Direct and indirect effects of atmospheric conditions and soil moisture on surface energy partitioning revealed by a prolonged drought at a temperate forest site, J. Geophys. Res.Atmos., 111, D16102, doi:10.1029/2006JD007161, 2006.

Hillel: Introduction to environmental soil physics, Academic Press, 2004.

Hirano, T., Hirata, R., Fujinuma, Y., Saigusa, N., Yamamoto, S., Harazono, Y., Takada, M., Inukai, K., and Inoue, G.: $\mathrm{CO}_{2}$ and water vapor exchange of a larch forest in northern Japan, Tellus B, 55, 244-257, 2003.

Howard, E. A., Gower, S. T., Foley, J. A., and Kucharik, C. J.: Effects of logging on carbon dynamics of a jack pine forest in Saskatchewan, Canada, Glob. Change Biol., 10, 1267-1284, 2004.

Humes, K. S., Kustas, W. P., Moran, M. S., Nichols, W. D., and Weltz, M. A.: Variability of emissivity and surface temperature over a sparsely vegetated surface, Water Resour. Res., 30, 12991310, 1994.

Humphreys, E. R., Black, T. A., Morgenstern, K., Cai, T. B., Drewitt, G. B., Nesic, Z., and Trofymow, J. A.: Carbon dioxide fluxes in coastal Douglas-fir stands at different stages of development after clearcut harvesting, Agr. Forest Meteorol., 140, 6-22, 2006.

Ibrom, A., Jarvis, P., Clement, R., Morgenstern, K., Oltchev, A., Medlyn, B. E., Wang, Y. P., Wingate, L., Moncrieff, J., and Gravenhorst, G.: A comparative analysis of simulated and observed photosynthetic $\mathrm{CO}_{2}$ uptake in two coniferous forest canopies, Tree Physiol., 26, 845-864, 2006.

Janssens, I. A., Lankreijer, H., Matteucci, G., Kowalski, A. S., Buchmann, N., Epron, D., Pilegaard, K., Kutsch, W., Longdoz, B., Grünwald, T., Montagnani, L., Dore, S., Rebmann, C., Moors, E. J., Grelle, A., Rannik, Ü., Morgenstern, K., Oltchev, S., Clement, R., Gudmundsson, J., Minerbi, S., Berbigier, P., 
Ibrom, A., Moncrieff, J., Aubinet, M., Bernhofer, C., Jensen, N. O., Vesala, T., Granier, A., Schulze, E. D., Lindroth, A., Dolman, A. J., Jarvis, P. G., Ceulemans, R., and Valentini, R.: Productivity overshadows temperature in determining soil and ecosystem respiration across European forests, Global Change Biol., 7, 269-278, 2001.

Knohl, A., Schulze, E. D., Kolle, O., and Buchmann, N.: Large carbon uptake by an unmanaged 250-year-old deciduous forest in Central Germany, Agr. Forest Meteorol., 118, 151-167, 2003.

Knorr, W. and Kattge, J.: Inversion of terrestrial ecosystem model parameter values against eddy covariance measurements by Monte Carlo sampling, Glob. Change Biol., 11, 1333-1351, 2005

Kolari, P., Kulmala, L., Pumpanen, J., Launiainen, S., Ilvesniemi, H., Hari, P., and Nikinmaa, E.: $\mathrm{CO}_{2}$ exchange and component $\mathrm{CO}_{2}$ fluxes of a boreal Scots pine forest, Boreal Env. Res., 14, 761-783, 2009.

Kurbatova, J., Li, C., Varlagin, A., Xiao, X., and Vygodskaya, N.: Modeling carbon dynamics in two adjacent spruce forests with different soil conditions in Russia, Biogeosciences, 5, 969-980, doi:10.5194/bg-5-969-2008, 2008.

Lafleur, P. M., Roulet, N. T., Bubier, J. L., Frolking, S., and Moore, T. R.: Interannual variability in the peatland-atmosphere carbon dioxide exchange at an ombrotrophic bog, Global Biogeochem. Cy., 17, 1036, doi:10.1029/2002GB001983, 2003.

Lagergren, F., Lindroth, A., Dellwik, E., Ibrom, A., Lankreijer, H., Launiainen, S., Mölder, M., Kolari, P., Pilegaard, K., and Vesala, T.: Biophysical controls on $\mathrm{CO}_{2}$ fluxes of three Northern forets based on long-term eddy covariance data, Tellus B, 60, 143-152, 2008.

Lasslop, G., Reichstein, M., Papale, D., Richardson, A. D., Arneth, A., Barr, A., Stoy, P., and Wohlfahrt, G.: Separation of net ecosystem exchange into assimilation and respiration using a light response curve approach: critical issues and global evaluation, Glob. Change Biol., 16, 187-208, 2010.

Law, B. E., Falge, E., Gu, L., Baldocchi, D. D., Bakwin, P., Berbigier, P., Davis, K., Dolman, A. J., Falk, M., Fuentes, J. D., Goldstein, A., Granier, A., Grelle, A., Hollinger, D., Janssens, I. A., Jarvis, P., Jensen, N. O., Katul, G., Mahli, Y., Matteucci, G., Meyers, T., Monson, R., Munger, W., Oechel, W., Olson, R., Pilegaard, K., Paw, K. T., Thorgeirsson, H., Valentini, R., Verma, S., Vesala, T., Wilson, K., and Wofsy, S.: Environmental controls over carbon dioxide and water vapor exchange of terrestrial vegetation, Agr. Forest Meteorol., 113, 97-120, 2002.

Lipson, D. A., Wilson, R. F., and Oechel, W. C.: Effects of elevated atmospheric $\mathrm{CO}_{2}$ on soil microbial biomass, activity, and diversity in a chaparral ecosystem, Appl. Environ. Microbiol., 71, 8573-8580, 2005.

Lloyd, J. and Taylor, J. A.: On the Temperature Dependence of Soil Respiration, Funct. Ecol., 8, 315-323, 1994.

Mahecha, M. D., Reichstein, M., Carvalhais, N., Lasslop, G., Lange, H., Seneviratne, S. I., Vargas, R., Ammann, C., Arain, M. A., Cescatti, A., Janssens, I. A., Migliavacca, M., Montagnani, L., and Richardson, A. D.: Global convergence in the temperature sensitivity of respiration at ecosystem level, Science, 329, 838-840, doi:10.1126/science.1189587, 2010.

Mahecha, M., Reichstein, M., Carvalhais, N., Lasslop, G., Lange, H., Seneviratne, S., Vargas, R., Ammann, C., Arain, M., Cescatti, A., Janssens, I., Migliavacca, M., Montagnani, L., and Richard- son, A.: Response to comment on "Global convergence in the temperature sensitivity of respiration at ecosystem level" Science, 331, p. 1265, doi:10.1126/science.1197033, 2011.

Mauder, M., Foken, T., Clement, R., Elbers, J. A., Eugster, W., Grünwald, T., Heusinkveld, B., and Kolle, O.: Quality control of CarboEurope flux data - Part 2: Inter-comparison of eddy-covariance software, Biogeosciences, 5, 451-462, doi:10.5194/bg-5-451-2008, 2008.

Meyers, T. P. and Hollinger, S. E.: An assessment of storage terms in the surface energy balance of maize and soybean, Agr. Forest Meteorol., 125, 105-115, 2004.

Monson, R. K., Turnipseed, A. A., Sparks, J. P., Harley, P. C., ScottDenton, L. E., Sparks, K., and Huxman, T. E.: Carbon sequestration in a high-elevation, subalpine forest, Glob. Change Biol., 8, 459-478, 2002.

Monteith, J. L. and Unsworth, M.: Principles of Environmental Physics, Edward Arnold, London, 2 Edn., 1996.

Moureaux, C., Debacq, A., Bodson, B., Heinesch, B., and Aubinet, M.: Annual net ecosystem carbon exchange by a sugar beet crop, Agri. Forest Meteorol., 139, 25-39, 2006.

Nagy, Z., Pinter, K., Czobel, S., Balogh, J., Horvath, L., Foti, S., Barcza, Z., Weidinger, T., Csintalan, Z., Dinh, N. Q., Grosz, B., and Tuba, Z.: The carbon budget of semi-arid grassland in a wet and a dry year in Hungary, Agr. Ecosy. Environ., 121, 21-29, 2007.

Nave, L., Gough, C. M., Maurer, K., Bohrer, G., Hardiman, B. S., Le Moine, J., Munoz, A., Nadelhoffer, K. J., Sparks, J. P., Strahm, B., Vogel, C. S., and Curtis, P. S.: Disturbance and the resilience of coupled carbon and nitrogen cycling in a north temperate forest, J. Geophys. Res.-Biogeosci., 116, G04016, doi:10.1029/2011JG001758, 2011.

Papale, D., Reichstein, M., Aubinet, M., Canfora, E., Bernhofer, C., Kutsch, W., Longdoz, B., Rambal, S., Valentini, R., Vesala, T., and Yakir, D.: Towards a standardized processing of Net Ecosystem Exchange measured with eddy covariance technique: algorithms and uncertainty estimation, Biogeosciences, 3, 571-583, doi:10.5194/bg-3-571-2006, 2006.

Phillips, C. L., Nickerson, N., Risk, D., and Bond, B. J.: Interpreting diel hysteresis between soil respiration and temperature, Glob. Change Biol., 17, 515-527, doi:10.1111/j.13652486.2010.02250.x, 2011.

Pilegaard, K., Mikkelsen, T. N., Beier, C., Jensen, N. O., Ambus, P., and Ro-Poulsen, H.: Field measurements of atmospherebiosphere interactions in a Danish beech forest, Boreal Environ. Res., 8, 315-333, 2003.

Pilegaard, K., Ibrom, A., Courtney, M. S., Hummelshj, P., and Jensen, N. O.: Increasing net $\mathrm{CO}_{2}$ uptake by a Danish beech forest during the period from 1996 to 2009, Agr. Forest Meteorol., 151, 934-946, doi:10.1016/j.agrformet.2011.02.013, 2011.

Powell, T. L., Bracho, R., Li, J. H., Dore, S., Hinkle, C. R., and Drake, B. G.: Environmental controls over net ecosystem carbon exchange of scrub oak in central Florida, Agr. Forest Meteorol., 141, 19-34, 2006.

Powell, T. L., Gholz, H. L., Clark, K. L., Starr, G., Cropper, W. P., and Martin, T. A.: Carbon exchange of a mature, naturally regenerated pine forest in north Florida, Glob. Change Biol., 14, 2523-2538, 2008.

Prescher, A.-K., Gruenwald, T., and Bernhofer, C.: Land use regulates carbon budgets in eastern Germany: From 
NEE to NBP, Agr. Forest Meteorol., 150, 1016-1025, doi:10.1016/j.agrformet.2010.03.008, 2010.

R Development Core Team: R: A Language and Environment for Statistical Computing, R Foundation for Statistical Computing, Vienna, Austria, http://www.R-project.org/, ISBN 3-900051-070, 2010.

Rebmann, C., Gockede, M., Foken, T., Aubinet, M., Aurela, M., Berbigier, P., Bernhofer, C., Buchmann, N., Carrara, A., Cescatti, A., Ceulemans, R., Clement, R., Elbers, J. A., Granier, A., Grünwald, T., Guyon, D., Havrankova, K., Heinesch, B., Knohl, A., Laurila, T., Longdoz, B., Marcolla, B., Markkanen, T., Miglietta, F., Moncrieff, J., Montagnani, L., Moors, E., Nardino, M., Ourcival, J. M., Rambal, S., Rannik, Ü., Rotenberg, E., Sedlak, P., Unterhuber, G., Vesala, T., and Yakir, D.: Quality analysis applied on eddy covariance measurements at complex forest sites using footprint modelling, Theor. Appl. Climatol., 80, 121-141, 2005.

Rebmann, C., Zeri, M., Lasslop, G., Mund, M., Kolle, O., Schulze, E.-D., and Feigenwinter, C.: Treatment and assessment of the $\mathrm{CO}_{2}$-exchange at a complex forest site in Thuringia Germany, Agr. Forest Meteorol., 150, 684-691, 2010.

Reichstein, M., Rey, A., Freibauer, A., Tenhunen, J., Valentini, R., Banza, J., Casals, P., Cheng, Y. F., Grünzweig, J. M., Irvine, J., Joffre, R., Law, B. E., Loustau, D., Miglietta, F., Oechel, W., Ourcival, J. M., Pereira, J. S., Peressotti, A., Ponti, F., Qi, Y., Rambal, S., Rayment, M., Romanya, J., Rossi, F., Tedeschi, V., Tirone, G., $\mathrm{Xu}, \mathrm{M}$., and Yakir, D.: Modeling temporal and large-scale spatial variability of soil respiration from soil water availability, temperature and vegetation productivity indices, Global Biogeochem. Cy., 17, 1104, doi:10.1029/2003GB002035, 2003 a.

Reichstein, M., Tenhunen, J., Roupsard, O., Ourcival, J. M., Rambal, S., Miglietta, F., Peressotti, A., Pecchiari, M., Tirone, G., and Valentini, R.: Inverse modeling of seasonal drought effects on canopy $\mathrm{CO}_{2} / \mathrm{H}_{2} \mathrm{O}$ exchange in three Mediterranean ecosystems, J. Geophys. Res.-Atmos., 108, 4726, doi:10.1029/2003JD003430, 2003b.

Reichstein, M., Falge, E., Baldocchi, D., Papale, D., Aubinet, M., Berbigier, P., Bernhofer, C., Buchmann, N., Gilmanov, T., Granier, A., Grünwald, T., Havrankova, K., Ilvesniemi, H., Janous, D., Knohl, A., Laurila, T., Lohila, A., Loustau, D., Matteucci, G., Meyers, T., Miglietta, F., Ourcival, J. M., Pumpanen, J., Rambal, S., Rotenberg, E., Sanz, M., Tenhunen, J., Seufert, G., Vaccari, F., Vesala, T., Yakir, D., and Valentini, R.: On the separation of net ecosystem exchange into assimilation and ecosystem respiration: review and improved algorithm, Glob. Change Biol., 11, 1424-1439, 2005.

Rey, A., Pegoraro, E., Tedeschi, V., Parri, I. D., Jarvis, P., and Valentini, R.: Annual variation in soil respiration and its components in a coppice oak forest in central italy, Glob. Change Biol., 9, 851-866, 2002.

Richardson, A. D., Black, T. A., Ciais, P., Delbart, N., Friedl, M. A., Gobron, N., Hollinger, D. Y., Kutsch, W. L., Longdoz, B., Luyssaert, S., Migliavacca, M., Montagnani, L., Munger, J. W., Moors, E., Piao, S., Rebmann, C., Reichstein, M., Saigusa, N., Tomelleri, E., Vargas, R., and Varlagin, A.: Influence of spring and autumn phenological transitions on forest ecosystem productivity, Philos. T. Roy. Soc. London Series B, Biological Sciences, 365, 3227-3246, 2010.
Saito, M., Miyata, A., Nagai, H., and Yamada, T.: Seasonal variation of carbon dioxide exchange in rice paddy field in Japan, Agr. Forest Meteorol., 135, 93-109, 2005.

Sakai, R. K., Fitzjarrald, D. R., Moraes, O. L. L., Staebler, R. M., Acevedo, O. C., Czikowsky, M. J., Da Silva, R., Brait, E., and Miranda, V.: Land-use change effects on local energy, water, and carbon balances in an Amazonian agricultural field, Glob. Change Biol., 10, 895-907, 2004.

Schindler, D., Turk, M., and Mayer, $\mathrm{H}$.: $\mathrm{CO}_{2}$ fluxes of a Scots pine forest growing in the warm and dry southern upper Rhine plain, SW Germany, European J. Forest Res., 125, 201-212, 2006.

Schmid, H. P., Grimmond, C. S. B., Cropley, F., Offerle, B., and $\mathrm{Su}, \mathrm{H}$. B.: Measurements of $\mathrm{CO}_{2}$ and energy fluxes over a mixed hardwood forest in the mid-western United States, Agr. Forest Meteorol., 103, 357-374, 2000.

Staudt, K. and Foken, T.: Documentation of reference data for the experimental areas of the Bayreuth Centre for Ecology and Environmental Research (BayCEER) at the Waldstein site, Tech. Rep. 35, University of Bayreuth, 2007.

Stoy, P. C., Richardson, A. D., Baldocchi, D. D., Katul, G. G., Stanovick, J., Mahecha, M. D., Reichstein, M., Detto, M., Law, B. E., Wohlfahrt, G., Arriga, N., Campos, J., McCaughey, J. H., Montagnani, L., Paw, U. K. T., Sevanto, S., and Williams, M.: Biosphere-atmosphere exchange of $\mathrm{CO}_{2}$ in relation to climate: a cross-biome analysis across multiple time scales, Biogeosciences, 6, 2297-2312, doi:10.5194/bg-6-2297-2009, 2009.

Subke, J.-A. and Bahn, M.: On the "temperature sensitivity" of soil respiration: Can we use the immeasurable to predict the unknown?, Soil Biol. Biochem., 42, 1653-1656, doi:10.1016/j.soilbio.2010.05.026, 2010.

Suni, T., Berninger, F., Vesala, T., Markkanen, T., Hari, P., Mäkelä, A., Ilvesniemi, H., Hänninen, H., Nikinmaa, E., Huttula, T., Laurila, T., Aurela, M., Grelle, A. A. L., Arneth, A., Shibistova, O., and Lloyd, J.: Air temperature triggers the commencement of evergreen boreal forest photosynthesis in spring, Glob. Change Biol., 9, 1410-1426, 2003a.

Suni, T., Rinne, J., Reissell, A., Altimir, N., Keronen, P., Rannik, Ü., Dal Maso, M., Kulmala, M., and Vesala, T.: Long-term measurements of surface fluxes above a Scots pine forest in Hyytiala, southern Finland, 1996-2001, Boreal Environ. Res., 8, 287-301, 2003b.

Syed, K. H., Flanagan, L. B., Carlson, P. J., Glenn, A. J., and Van Gaalen, K. E.: Environmental control of net ecosystem $\mathrm{CO}_{2}$ exchange in a treed, moderately rich fen in northern Alberta, Agr. Forest Meteorol., 140, 97-114, 2006.

Tedeschi, V., Rey, A., Manca, G., Valentini, R., Jarvis, P. G., and Borghetti, M.: Soil respiration in a Mediterranean oak forest at different developmental stages after coppicing, Glob. Change Biol., 12, 110-121, 2006.

Teuling, A. J., Seneviratne, S. I., Stockli, R., Reichstein, M., Moors, E., Ciais, P., Luyssaert, S., van den Hurk, B., Ammann, C., Bernhofer, C., Dellwik, E., Gianelle, D., Gielen, B., Grünwald, T., Klumpp, K., Montagnani, L., Moureaux, C., Sottocornola, M., and Wohlfahrt, G.: Contrasting response of European forest and grassland energy exchange to heatwaves, Nature Geosci., 3, 722727, 2010.

Urbanski, S., Barford, C., Wofsy, S., Kucharik, C., Pyle, E., Budney, J., McKain, K., Fitzjarrald, D., Czikowsky, M., and Munger, J. W.: Factors controlling $\mathrm{CO}_{2}$ exchange on timescales from 
hourly to decadal at Harvard Forest, J. Geophys. Res., 112, G02020, doi:10.1029/2006JG000293, 2007.

van Gorsel, E., Leuning, R., Cleugh, H. A., Keith, H., Kirschbaum, M. U. F., and Suni, T.: Application of an alternative method to derive reliable estimates of nighttime respiration from eddy covariance measurements in moderately complex topography, Agr. Forest Meteorol., 148, 1174-1180, 2008.

Veenendaal, E. M., Kolle, O., and Lloyd, J.: Seasonal variation in energy fluxes and carbon dioxide exchange for a broad-leaved semi-arid savanna (Mopane woodland) in Southern Africa, Glob. Change Biol., 10, 318-328, 2004.

Verma, S. B., Dobermann, A., Cassman, K. G., Walters, D. T., Knops, J. M., Arkebauer, T. J., Suyker, A. E., Burba, G. G., Amos, B., Yang, H. S., Ginting, D., Hubbard, K. G., Gitelson, A. A., and Walter-Shea, E. A.: Annual carbon dioxide exchange in irrigated and rainfed maize-based agroecosystems, Agr. Forest Meteorol., 131, 77-96, 2005.

Vickers, D., Thomas, C., and Law, B. E.: Random and systematic $\mathrm{CO}_{2}$ flux sampling errors for tower measurements over forests in the convective boundary layer, Agr. Forest Meteorol., 149, $73-$ 83, 2009.

Visual Numerics, I.: PV-Wave 8.5 Reference Guide, available at: http://www.vni.com/books/dod/pdf/wave85Docs/ eReferenceGuide85.pdf (last access: 18 December 2008), 2005.

Wilson, K. B. and Baldocchi, D. D.: Comparing independent estimates of carbon dioxide exchange over 5 years at a deciduous forest in the southeastern United States, J. Geophys. Res., 106, 34167-34178, 2001.
Wohlfahrt, G., Hammerle, A., Haslwanter, A., Bahn, M., Tappeiner, U., and Cernusca, A.: Seasonal and inter-annual variability of the net ecosystem $\mathrm{CO}_{2}$ exchange of a temperate mountain grassland: Effects of weather and management, J. Geophys. Res.-Atmos., 113, D08110, doi:10.1029/2007JD009286, 2008.

$\mathrm{Xu}$, L. and Baldocchi, D. D.: Seasonal variation in carbon dioxide exchange over a Mediterranean annual grassland in California, Agr. Forest Meteorol., 123, 79-96, 2004.

Yan, Y., Zhao, B., Chen, J. Q., Guo, H. Q., Gu, Y. J., Wu, Q. H., and $\mathrm{Li}, \mathrm{B}$. : Closing the carbon budget of estuarine wetlands with tower-based measurements and MODIS time series, Glob. Change Biol., 14, 1690-1702, 2008.

Zha, T., Niinisto, S., Xing, Z., Wang, K., Kellomaki, S., and Barr, A.: Total and component carbon fluxes of a scots pine ecosystem from chamber measurements and eddy covariance, Ann. Bot., 99, 345-353, 2006.

Zha, T., Barr, A. G., Black, T. A., McCaughey, J. H., Bhatti, J., Hawthorne, I., Krishnan, P., Kidston, J., Saigusa, N., Shashkov, A., and Nesic, Z.: Carbon sequestration in boreal jack pine stands following harvesting, Glob. Change Biol., 15, 1475-1487, 2009.

Zheng, D., Hunt Jr., E. R., and Running, S.: A daily soil temperature model based on air temperature and precipitation for continental applications, Climate Res., 2, 183-191, 1993. 